\title{
Identification of abiotic and biotic reductive dechlorination in a chlorinated ethene plume after thermal source remediation by means of isotopic and molecular biology tools
}

Badin, Alice; Broholm, Mette Martina; Jacobsen, Carsten S.; Palau, Jordi; Dennis, Philip; Hunkeler, Daniel

Published in:

Journal of Contaminant Hydrology

Link to article, DOI:

10.1016/j.jconhyd.2016.05.003

Publication date:

2016

Document Version

Publisher's PDF, also known as Version of record

Link back to DTU Orbit

Citation (APA):

Badin, A., Broholm, M. M., Jacobsen, C. S., Palau, J., Dennis, P., \& Hunkeler, D. (2016). Identification of abiotic and biotic reductive dechlorination in a chlorinated ethene plume after thermal source remediation by means of isotopic and molecular biology tools. Journal of Contaminant Hydrology, 192, 1-19.

https://doi.org/10.1016/j.jconhyd.2016.05.003

\section{General rights}

Copyright and moral rights for the publications made accessible in the public portal are retained by the authors and/or other copyright owners and it is a condition of accessing publications that users recognise and abide by the legal requirements associated with these rights.

- Users may download and print one copy of any publication from the public portal for the purpose of private study or research.

- You may not further distribute the material or use it for any profit-making activity or commercial gain

- You may freely distribute the URL identifying the publication in the public portal 


\title{
Identification of abiotic and biotic reductive dechlorination in a chlorinated ethene plume after thermal source remediation by means of isotopic and molecular biology tools
}

\author{
Alice Badin ${ }^{\mathrm{a}}$, Mette M. Broholm ${ }^{\mathrm{b}}$, Carsten S. Jacobsen ${ }^{\mathrm{c}}$, Jordi Palau ${ }^{\mathrm{a}}$, \\ Philip Dennis ${ }^{\mathrm{d}}$, Daniel Hunkeler ${ }^{\mathrm{a}, *}$ \\ a University of Neuchâtel, Centre for Hydrogeology \& Geothermics (CHYN), Rue Emile Argand 11, CH 2000 Neuchâtel, Switzerland \\ b Technical University of Denmark (DTU), Department of Environmental Engineering, Miljøvej, DTU B113, DK 2800 Kgs. Lyngby, Denmark \\ c Geological Survey of Denmark and Greenland (GEUS), Department of Geochemistry, Ø. Voldgade 10, 1350 København K, Denmark \\ d SiREM, 130 Research Lane, Guelph, Ontario, N1G5G3, Canada
}

\section{A R T I C L E I N F O}

\section{Article history:}

Received 23 December 2015

Received in revised form 6 May 2016

Accepted 17 May 2016

Available online 26 May 2016

\section{Keywords:}

Chloroethenes

Stable isotopes

Molecular biology

Thermal treatment

\begin{abstract}
A B S T R A C T
Thermal tetrachloroethene (PCE) remediation by steam injection in a sandy aquifer led to the release of dissolved organic carbon (DOC) from aquifer sediments resulting in more reduced redox conditions, accelerated PCE biodegradation, and changes in microbial populations. These changes were documented by comparing data collected prior to the remediation event and eight years later. Based on the premise that dual $\mathrm{C}-\mathrm{Cl}$ isotope slopes reflect ongoing degradation pathways, the slopes associated with PCE and TCE suggest the predominance of biotic reductive dechlorination near the source area. PCE was the predominant chlorinated ethene near the source area prior to thermal treatment. After thermal treatment, $c D C E$ became predominant. The biotic contribution to these changes was supported by the presence of Dehalococcoides sp. DNA (Dhc) and $\mathrm{Dhc}$ targeted rRNA close to the source area. In contrast, dual C-Cl isotope analysis together with the almost absent $\mathrm{VC}{ }^{13} \mathrm{C}$ depletion in comparison to $\mathrm{CDCE}{ }^{13} \mathrm{C}$ depletion suggested that $c \mathrm{DCE}$ was subject to abiotic degradation due to the presence of pyrite, possible surface-bound iron (II) or reduced iron sulphides in the downgradient part of the plume. This interpretation is supported by the relative lack of $D h c$ in the downgradient part of the plume. The results of this study show that thermal remediation can enhance the biodegradation of chlorinated ethenes, and that this effect can be traced to the mobilisation of DOC due to steam injection. This, in turn, results in more reduced redox conditions which favor active reductive dechlorination and/or may lead to a series of redox reactions which may consecutively trigger biotically induced abiotic degradation. Finally, this study illustrates the valuable complementary application of compound-specific isotopic analysis combined with molecular biology tools to evaluate which biogeochemical processes are taking place in an aquifer contaminated with chlorinated ethenes.
\end{abstract}

(c) 2016 Elsevier B.V. All rights reserved.

\section{Introduction}

Management of sites contaminated with chlorinated ethenes is known to be challenging. Among the various developed remediation methods, thermal treatment by steam injection is

\footnotetext{
* Corresponding author.
}

particularly adapted for source treatment in subsurface sediments of relatively high permeability such as sandy aquifers (von Schnakenburg, 2013).This remediation strategy is known to release dissolved organic carbon (DOC) (Friis et al., 2005) the increase of which may trigger a chain of microbiallymediated redox processes. When natural attenuation has been observed prior to active source remediation, steam injection might thus influence the naturally occurring degradation. 
Natural degradation of chlorinated ethenes might occur biotically due to the presence of adequate active microorganisms in specific redox conditions, as well as abiotically in the presence of reduced iron (Fe) minerals. Sequential biotic reductive dechlorination of the ubiquitous groundwater contaminant tetrachloroethene (PCE) consecutively yields trichloroethene (TCE), cis-dichloroethene ( $c$ DCE), vinyl chloride $(\mathrm{VC})$ and eventually non-toxic ethene. This process takes place in strictly anaerobic systems (Wiedemeier et al., 1999; Bradley, 2000) and is the most commonly encountered naturally occurring biotic degradation of chlorinated ethenes. According to laboratory and field observations, PCE could undergo reductive dechlorination in virtually all anaerobic conditions while reductive TCE, $c D C E$ and VC dechlorination would generally occur in more reduced conditions, such as ironreducing for TCE and ideally sulfate-reducing to methanogenic for cDCE and VC (Vogel et al., 1987; Chapelle, 1996; Bradley, 2000; Tiehm and Schmidt, 2011). The presence of and competition for molecular hydrogen $\left(\mathrm{H}_{2}\right)$, a key electron donor, can also be a determining factor (Ballapragada et al., 1997). Depending on its mineralogy, the presence of iron may also induce competitive inhibition of chlorinated ethene biotic reductive dechlorination (Paul et al., 2013). The occurrence of reductive dechlorination further depends on the presence and activity of specific dechlorinating microorganisms. Members from various bacterial genera such as Sulfurospirillum, Dehalobacter, Desulfitobacterium, Desulfuromonas or Geobacter have been reported to catalyze some steps of chlorinated ethene reductive dechlorination. However, while some enrichment cultures and consortia are able to dechlorinate to ethene (Flynn et al., 2000; Aulenta et al., 2002; Duhamel et al., 2002; Hoelen and Reinhard, 2004), to date, the only organisms which have been reported to catalyze complete reductive dechlorination to ethene are some species of the genus Dehalococcoides (Dhc) (Löffler et al., 2013). cDCE is hence often found to accumulate in the subsurface. Microbial oxidation might also take place, particularly in the case of $C D C E$ and VC (Hartmans et al., 1985; Bradley and Chapelle, 1998, Bradley and Chapelle, 2000). Despite their presence in the subsurface, microorganisms may display a low activity, are sometimes inactive or are even dormant (Meckenstock et al., 2015), which may additionally hinder reductive dechlorination. Abiotic reductive dechlorination can also take place naturally, provided that the adequate minerals and geochemical conditions are present. Iron sulphides such as mackinawite $\left(\mathrm{Fe}^{\mathrm{II}} \mathrm{S}\right)$ or pyrite $\left(\mathrm{Fe}^{\mathrm{II}} \mathrm{S}_{2}\right)$, iron oxides such as magnetite $\left(\mathrm{Fe}^{\mathrm{II}} \mathrm{O} \cdot \mathrm{Fe}^{\mathrm{III}}{ }_{2} \mathrm{O}_{3}\right)$, and iron hydroxides such as green rusts, which are corrosion products

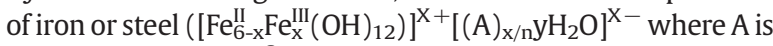
an anion, typically $\mathrm{SO}_{4}^{2-}$ or $\left.\mathrm{Cl}^{-}\right)$, have been reported to catalyze abiotic reductive degradation yielding less chlorinated compounds and other non-toxic compounds such as acetylene in various proportions (Tobiszewski and Namieśnik, 2012). Pyrite is known to reduce all chlorinated ethenes (Lee and Batchelor, 2002a) while mackinawite was shown to reduce PCE and TCE but was non-reactive with cDCE (Butler and Hayes, 1999, Jeong et al., 2011). Surface-bound Fe(II) is also known to catalyze abiotic degradation of reducible contaminants (Elsner et al., 2004; McCormick and Adriaens, 2004, Han et al., 2012). Furthermore, the activity of various bacteria in the subsurface may change the local redox conditions. This might affect the redox potential of metals contained in minerals, which might in turn affect the likelihood that biotically induced abiotic degradation will take place (Tobiszewski and Namieśnik, 2012).

In order to explore the occurrence of such processes in the subsurface and thus evaluate the effect of remediation or site management, various tools may be employed.

In recent decades, compound specific isotopic analysis has been increasingly used to explore chlorinated ethene degradation processes. It was demonstrated that the extent of biodegradation could be determined based on isotopic measurements (Hunkeler et al., 2010). Additionally, it was suggested that dual $\mathrm{C}-\mathrm{Cl}$ isotopic analysis may help to differentiate degradation pathways, for example biotic from abiotic degradation (Elsner et al., 2005; Abe et al., 2009; AudíMiró et al., 2013) despite some limitations (Badin et al., 2014; Renpenning et al., 2014). The range of laboratory determined dual $\mathrm{C}-\mathrm{Cl}$ isotope slopes associated with various chlorinated ethene degradation processes has increased in recent years, thus enriching the database to which dual $\mathrm{C}-\mathrm{Cl}$ isotope slopes measured in the field can be compared for process identification (Fig. 1) (Abe et al., 2009; Audí-Miró et al., 2013; Cretnik et al., 2013; Kuder et al., 2013; Wiegert et al., 2013; Badin et al., 2014; Cretnik et al., 2014; Renpenning et al., 2014). Moreover, rapid advances in molecular biology open new possibilities for the characterization of microbial communities present in the subsurface and the assessment of their activity based on mRNA analysis. For example bacterial 16S rRNA gene pool characterization via amplicon pyrosequencing can be used to identify the present bacterial communities in high detail (Novais and Thorstenson, 2011). It was moreover demonstrated that pyrotag sequencing is a robust and reproducible method that can be used for reliable microbial community exploration in natural systems (Pilloni et al., 2012). Additionally, as cDCE and VC degradation usually represents the bottle neck of chlorinated ethene natural attenuation, it is essential to screen for markers of their degradation. Dhc screening has thus been carried out in numerous studies since it is the only class of microorganisms reported to perform $c$ DCE and VC dechlorination. Furthermore, assessing the presence of genes that encode for $\mathrm{VC}$ reductive dehalogenases $(r d h A)$ known to catalyze VC reduction to ethene, such as $v c r A$, and measuring genes' mRNA level constitutes a stronger line of evidence to support complete reductive dechlorination. The vcrA and bvcA genes identified in $D h c$ are so far the only two functional genes described to encode VC $r d h A$ (Krajmalnik-Brown et al., 2004; Müller et al., 2004) and their presence in field samples from sites contaminated with chlorinated ethenes was successfully related to complete dechlorination (Scheutz et al., 2008; van der Zaan et al., 2010; Damgaard et al., 2013a). It was moreover shown based on field samples that $r d h A$ genes directly involved in dechlorination should be targeted in addition to Dhc, as different microbial species might harbour $v c r A$ and $b v c A$ genes due to horizontal gene transfer and are therefore also able to dechlorinate VC down to ethene (van der Zaan et al., 2010). Finally, targeting mRNA constitutes an essential complementary analysis as it will additionally inform on the activity of the corresponding degrader (Bælum et al., 2013).

Here we combine such innovative methods to assess the impact of source remediation by steam injection on a chlorinated ethene plume that occurrs in a complex biogeochemical system where iron minerals are present. More 


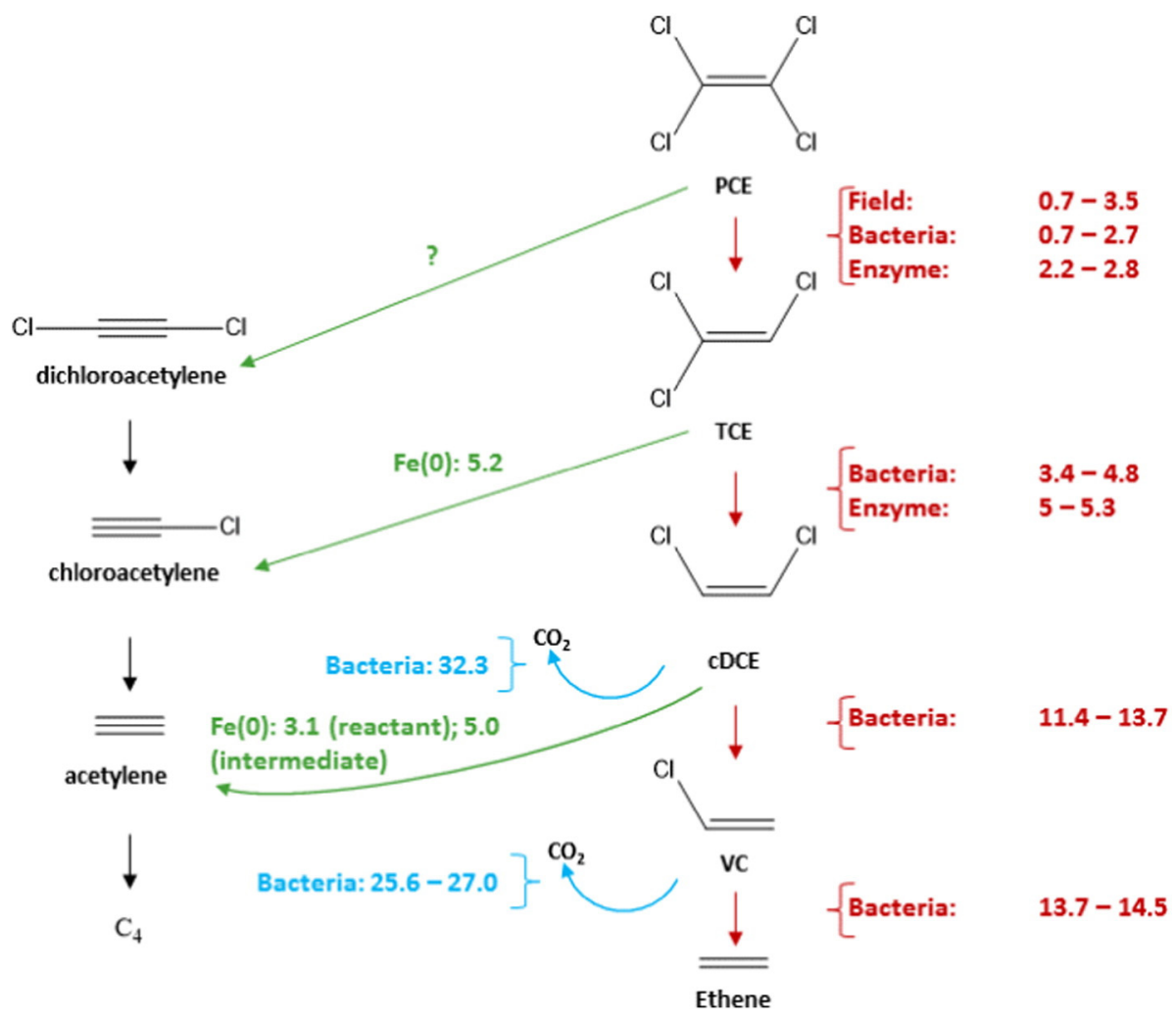

Fig. 1. Literature values for dual C-Cl isotope slopes associated with various degradation pathways of chlorinated ethenes (Abe et al., 2009; Audí-Miró et al., 2013; Cretnik et al., 2013; Kuder et al., 2013; Badin et al., 2014; Cretnik et al., 2014; Renpenning et al., 2014). Slopes are given for each of the substrates. Green arrows represent dihaloelimination, i.e. the main pathway for abiotic reduction, which typically occurrs in presence of zero-valent Fe. Blue arrows represent aerobic oxidation of chlorinated ethenes. Red arrows correspond to hydrogenolysis occurring during reductive dechlorination mediated by bacteria via their specific corrinoid-containing reductive dehalogenase enzymes. Dual $\mathrm{C}-\mathrm{Cl}$ isotope slopes associated with hydrogenolysis by these enzymes and corrinoids as well as by chemical models mimicking corrinoids (cobalamin, cobaloxime) were also recently reported (Renpenning et al., 2014). However, due to the lack of correlations between these slopes and slopes associated with bacterially mediated dechlorination, these values are not reported here. (For interpretation of the references to color in this figure legend, the reader is referred to the web version of this article.)

specifically, the aim was to evaluate if a plume detachment occurred due to steam injection as reported by a previous study (Sleep and Ma, 1997), and in addition, if natural degradation was stimulated by the thermal treatment.

A major advantage of this field site resides in the fact that the plume was formerly well characterized and studied (Hunkeler et al., 2011), which allows for comparison between before and after (7-8 years later) source remediation. An extensive campaign was carried out to evaluate the impact of steam injection where redox parameters, chlorinated ethene concentrations and isotopic compositions thereof, 454 pyrotag sequencing, Dhc DNA and rRNA, bvcA and vcrA functional genes, and gene transcripts (mRNA) were analysed in samples taken from 20 wells at different screening depths along the plume flow line.

\section{Materials and methods}

\subsection{Study site description}

The studied site previously described by Hunkeler et al. is located in southern Jutland, Denmark, in the town of Rødekro (Hunkeler et al., 2011). Briefly, the original PCE groundwater contamination comes from a dry-cleaning facility which operated between 1964 and 2001. A sandy aquifer $>50 \mathrm{~m}$ thick occasionally containing less permeable silt and clay lenses was characterized based on former site characterization campaigns. A chlorinated ethene plume of $\sim 2 \mathrm{~km}$ length that follows the groundwater flow (Fig. 2) southward from the site and turns southeast after $1 \mathrm{~km}$ was identified based on extensive monitoring well cover (55 multilevels). The difference in equipotential lines between 2006 and 2014 indicates that the gradient is less steep in 2014 than in 2006 (Fig. 2). Low amounts of organic matter as well as high levels of iron are expected in aquifers in this part of Jutland (Postma et al., 1991). An average groundwater velocity of $0.24 \mathrm{~m} \cdot$ day $^{-1}$ was previously estimated (Hunkeler et al., 2011), though this may vary locally due to different hydraulic conductivities resulting from the large grain size distribution.

Thermal remediation by steam injection was applied to the source zone between October and December 2006. The entire plume was sampled in 2006 before remediation and some points further out in the plume that were not yet impacted by remediation were sampled in 2007. The data previously discussed by Hunkeler et al. (Hunkeler et al., 2011) consist of data collected during these two sampling campaigns and are referred to as data from 2006, for simplification purposes. The main conclusions drawn from the previous campaign were that 


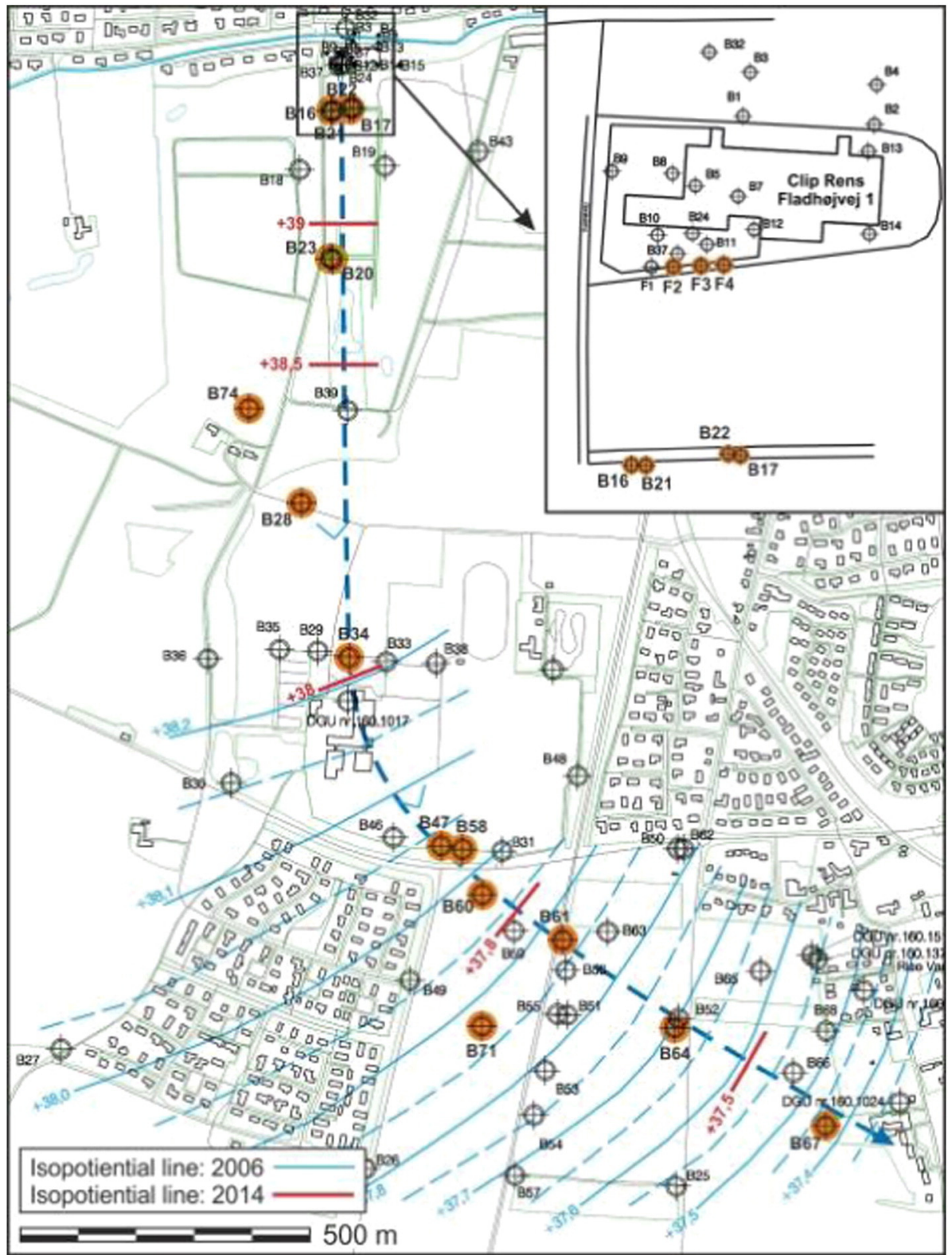

Fig. 2. Groundwater equipotential lines from 2006 (blue) and 2014 (red), approximate plume flow line (blue dashed arrow) and monitoring wells (grey and orange targets). Wells sampled in 2014 appear in orange. (For interpretation of the references to color in this figure legend, the reader is referred to the web version of this article.)

(i) PCE and TCE were likely biotically degraded by reductive dechlorination in the first $400 \mathrm{~m}$ downgradient of the source, (ii) $c D C E$ was not affected by degradation (neither biotic nor biotically induced abiotic) in the first $1050 \mathrm{~m}$ downgradient from the source, but it was degraded between 1050 and $1900 \mathrm{~m}$ downgradient, likely at least partially by biotic reductive dechlorination, and (iii) VC was transformed further by undetermined processes. The process responsible for $c \mathrm{DCE}$ degradation remained uncertain due to the lack in dual $\mathrm{C}-\mathrm{Cl}$ studies associated with abiotic reductive dechlorination of cDCE to which the dual C- $\mathrm{Cl}$ slope observed in Rødekro could be compared.
Concentrations of redox species and chlorinated ethenes were regularly measured between 2004 and 2014 as part of the monitoring process. The evolution of redox species between 2004 and 2014 is given in Fig. 3 B for sampling points from the plume centerline located close to the source (B16-1; $100 \mathrm{~m}$ ), in the middle of the plume (B34-4; $1050 \mathrm{~m}$ ) and at the front of the plume (B61-2; $1700 \mathrm{~m}$ ).

Based on the assessed average groundwater velocity, it can be estimated that species might have been transported about $600 \mathrm{~m}$ downgradient between the end of 2006 and the new campaign carried out in 2014. Such an estimation should however be treated cautiously as heterogeneities might change 
A
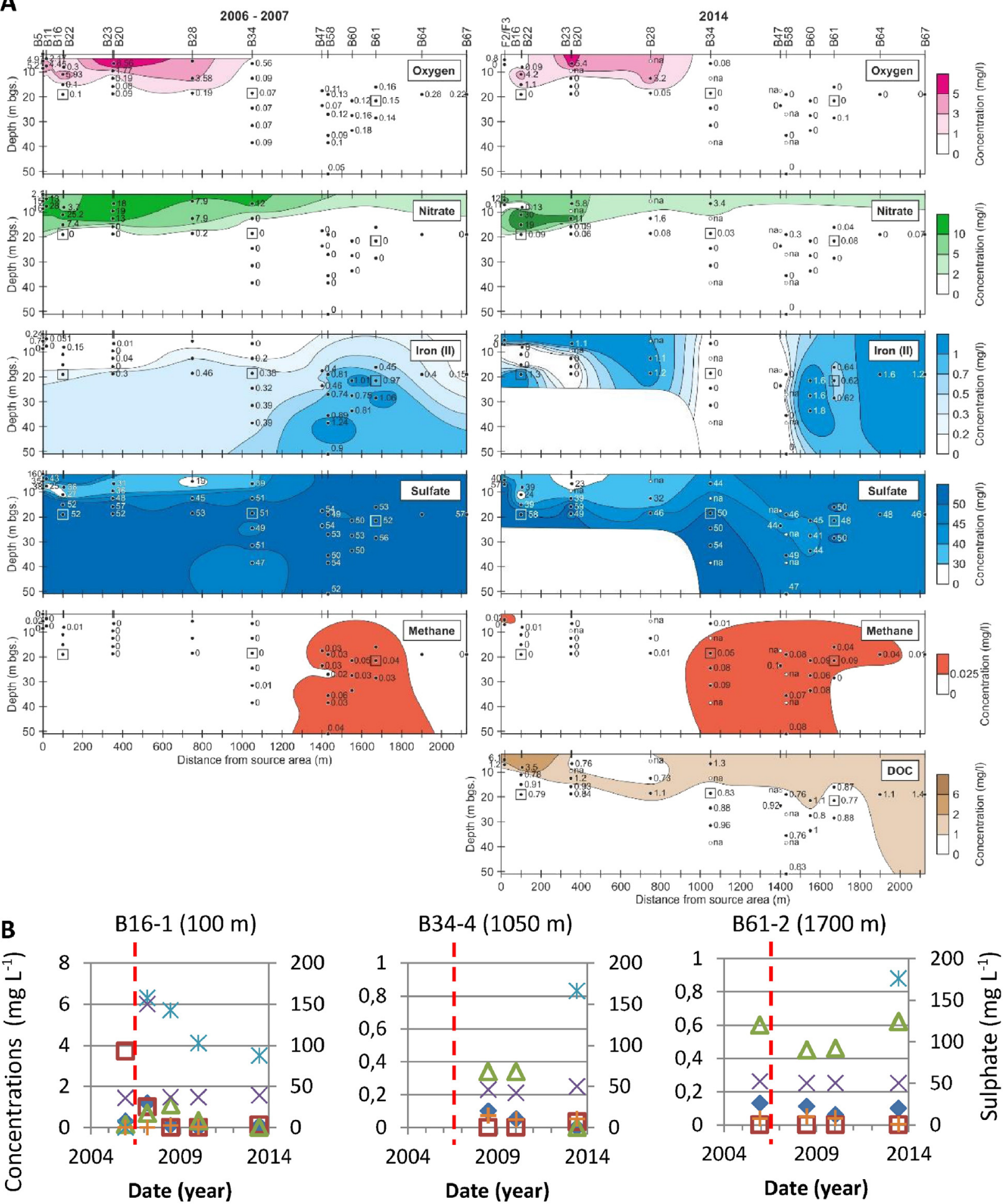

- $\mathrm{DO} \square \mathrm{NO} 3-\triangle \mathrm{Fe} 2+* \mathrm{DOC}+\mathrm{CH} 4 \times \mathrm{SO} 42-$

Fig. 3. A: Redox sensitive species concentrations in 2006 (Hunkeler et al., 2011) and 2014 (this study). B: Evolution of redox species concentrations between 2004 and 2014 along the plume centre line at $100 \mathrm{~m}$ (well B16-1), $1050 \mathrm{~m}$ (B34-4), and $1700 \mathrm{~m}$ (B61-2) downgradient from the source. These wells are "circled" in A. Dissolved oxygen (DO), nitrate $\left(\mathrm{NO}_{3}^{-}\right), \mathrm{Fe}(\mathrm{II})$, dissolved organic carbon (DOC) and methane $\left(\mathrm{CH}_{4}\right)$ concentrations are given by the left y-axis while sulfate ( $\left.\mathrm{SO}_{4}^{2-}\right)$ concentrations are given by the right y-axis. DOC concentrations were measured from the time of source remediation in B16-1 and only in 2014 in B34-4 and B61-2. The red dashed line corresponds to the source remediation event. Note that the left graph has a different left y-axis than the other two graphs. (For interpretation of the references to color in this figure legend, the reader is referred to the web version of this article.) 
the hydraulic conductivity by a few orders of magnitude in areas where different subsurface materials such as gravel/ coarse sand or fine sand/silt/clay lenses are present. Furthermore, with increasing distance and depth from the source, the clay lenses progressively disappear. This results in a divergence of the flow direction which causes the plume to dive deeper into the aquifer.

\subsection{Groundwater sampling}

Groundwater in 42 screens from 20 different locations was sampled in May 2014 after purging 3 times the volume of wells and checking the stability of $\mathrm{pH}$, temperature, dissolved oxygen $\left(\mathrm{O}_{2}\right)$ and conductivity. Samples for nitrate $\left(\mathrm{NO}_{3}^{-}\right)$and sulfate $\left(\mathrm{SO}_{4}^{2-}\right.$ ) analysis were collected in hard plastic bottles; samples for DOC were collected in glass bottles after filtration and spiked with $\mathrm{H}_{3} \mathrm{PO}_{4}$ upon arrival in the laboratory; samples for dissolved iron $(\mathrm{Fe}(\mathrm{II}))$ concentration were sampled in hard plastic bottles after filtration (sterile filter, $0.45 \mu \mathrm{m}$ ) and spiked with $\mathrm{HNO}_{3}$ (to $\mathrm{pH} 2$ ) upon arrival in the laboratory; samples for chlorinated ethene concentration were collected in $40 \mathrm{~mL}$ glass vials closed without headspace with a Teflon-coated cap and analysed upon arrival in the laboratory. Samples for chlorinated ethene isotope analysis were collected in $40 \mathrm{~mL}$ glass vials or $1 \mathrm{~L}$ Schott bottles (for isotope analysis with low chlorinated ethene concentrations) closed without headspace with a cap containing a Teflon-coated septum. $\mathrm{HNO}_{3}$ was added previously to the containers in order to reach $\mathrm{pH} 2$ when filled with the sample and to stop any microbial activity. Samples for methane, acetylene, ethene and ethane were collected in $6 \mathrm{~mL}$ Exetainer ${ }^{\circledR}$ glass vials (LabCo, UK) with $3 \mathrm{~mL}$ headspace which were previously evacuated and filled with $100 \mu \mathrm{L}$ concentrated $\mathrm{H}_{2} \mathrm{SO}_{4}$. Caution was taken so that no air bubbles were injected with the groundwater samples. All aqueous samples were stored in ice boxes topped with ice packs until arrival at the laboratory where they were stored at $4{ }^{\circ} \mathrm{C}$ until analysis. Samples for 454 pyrotag next generation sequencing analysis were collected by passing 300-400 mL of groundwater through Sterivex $^{\mathrm{TM}}$ Filters (EMD Millapore, Billerica, MA, USA) and were then shipped to Guelph (SIREM, commercial laboratory, Canada) with ice packs. Samples for Dhc DNA and rRNA, bvcA and $v c r A$ functional genes (DNA), and gene transcript (mRNA) analysis were collected as described previously in Bælum et al., 2013 snap-shot frozen in liquid $\mathrm{N}_{2}$ and kept at $-80{ }^{\circ} \mathrm{C}$ until analysis in Copenhagen (GEUS, Denmark).

\subsection{Analyses}

Chemical analyses: $\mathrm{NO}_{3}^{-}, \mathrm{Fe}(\mathrm{II}), \mathrm{SO}_{4}^{2-}$ and $\mathrm{DOC}$ were measured by accredited methods by the accredited (DANAK, International Standards Organization 17,025) laboratory ALS (ALS Denmark A/S, alsglobal.dk, alsglobal.com) in Denmark with quantification limits of $0.03 \mathrm{mg} \cdot \mathrm{L}^{-1}, 0.01 \mathrm{mg} \cdot \mathrm{L}^{-1}$, $0.5 \mathrm{mg} \cdot \mathrm{L}^{-1}$ and $0.1 \mathrm{mg} \cdot \mathrm{L}^{-1}$ respectively. Chlorinated ethene concentrations were analysed at ALS by Purge \& Trap Gas Chromatograph-Mass Spectrometer (GC-MS) with a detection limit of $0.02 \mu \mathrm{g} \cdot \mathrm{L}^{-1}$ and standard deviations of $10 \%$. Ethene, methane, ethane and acetylene were determined at the Technical University of Denmark (DTU, Kgs. Lyngby, Denmark) by headspace GC-Flame Ionisation Detector (FID) (Shimadzu GC.14 A with a packed column with 80/120 Carbopack B/3\% SP-
1500) with detection limits of $0.43 \mu \mathrm{g} \cdot \mathrm{L}^{-1}, 0.94 \mu \mathrm{g} \cdot \mathrm{L}^{-1}$, $0.47 \mu \mathrm{g} \cdot \mathrm{L}^{-1}$ and $0.38 \mu \mathrm{g} \cdot \mathrm{L}^{-1}$, respectively.

Isotopic analysis: $\mathrm{C}$ isotopic analysis was performed at the University of Neuchâtel (CHYN, Switzerland) by the system previously described for samples containing chlorinated ethene concentrations exceeding $5 \mu \mathrm{g} \cdot \mathrm{L}^{-1}$ (Badin et al., 2014), except that a QS-PLOT column was used instead of a DB-VRX to improve VC separation. The compounds degassed by $\mathrm{N}_{2}$ purging were retained on a Vocarb 3000 trap (VICI), transferred to a cryogenic trap (Tekmar Dohrmann) at $-120{ }^{\circ} \mathrm{C}$ to enable compound concentration, and sent to the gas chromatograph (GC) column (QS-PLOT, $30 \mathrm{~m}, 0.32 \mathrm{~mm}, 10 \mu \mathrm{m}$ ) of an Agilent ${ }^{\mathrm{TM}}$ 7890a GC for compound separation $\left(35^{\circ} \mathrm{C}\right.$ for 6 min, ramp of $15^{\circ} \mathrm{C} \cdot \mathrm{min}^{-1}$ until $130{ }^{\circ} \mathrm{C}$ kept for $0.1 \mathrm{~min}$ followed by a ramp of $20{ }^{\circ} \mathrm{C} \cdot \mathrm{min}^{-1}$ until $240{ }^{\circ} \mathrm{C}$ kept for $5 \mathrm{~min}$ ). After combustion via an Isoprime $\mathrm{GC} 5$ combustion interface, the resulting $\mathrm{CO}_{2}$ gas was sent to an Isoprime ${ }^{\mathrm{TM}} 100$ isotope ratio mass spectrometer (IRMS) to measure the $\mathrm{C}$ isotope ratio. Samples were measured in duplicate. Standard deviations $\sigma$ of the in-house reference materials measured in the same sequences as samples from the field site were $0.6 \%$ 。 $(n=32), 0.3 \%$ 。 $(n=24), 0.5 \%$ 。 $(n=24)$, $1.0 \%$ 。 $(n=26)$ for PCE, TCE, $c D C E$, and VC, respectively. The standard uncertainty of duplicate measurements was determined according to ISO guidelines (BIPM, 1993) as $\sigma / \sqrt{2}$, i.e. $0.4 \%$, $0.2 \%$, $0.3 \%$, $0.7 \%$ ofor PCE, TCE, $C D C E$, and VC, respectively. Samples that contained reference compounds with known isotope ratios (Elemental Analyser-IRMS measurement) were included in each sequence to verify the method accuracy except for VC which was not characterized by EA.

For the samples showing chlorinated ethene concentrations below $5 \mu \mathrm{g} \cdot \mathrm{L}^{-1}, 1 \mathrm{~L}$ bottles were manually connected to a purge system that consisted of a frit from a gas-washing bottle as described formerly (Hunkeler et al., 2012) instead of passing $40 \mathrm{~mL}$ glass vials by autosampler. The bottles were purged for $30 \mathrm{~min}$ at a rate of $150 \mathrm{~mL} \cdot \mathrm{min}^{-1}$ which led to a removal of 90 , 75, 50 and $100 \%$ of the dissolved PCE, TCE, cDCE and VC, respectively, considering Henry coefficients at $20{ }^{\circ} \mathrm{C}$ of 0.533 , $0.314,0.14,0.891$ (gas/water) for PCE, TCE, cDCE and VC, respectively.

$\mathrm{Cl}$ isotopic analysis of PCE and TCE was performed as previously described with an Agilent 7890 GC coupled to an Agilent 5975C quadrupole mass selective detector (Santa Clara, CA, USA) (Badin et al., 2014). A DB-5 column (30 m, $0.25 \mathrm{~mm}$, $0.25 \mu \mathrm{m}$, Agilent) with a constant helium flow of $1.2 \mathrm{~mL} \cdot \mathrm{min}^{-1}$ was used to perform chromatographic separation. Molecular ions were targeted and calculations were carried out according to the method developed by Aeppli et al., 2010. Calibration with two external standards $\left(\delta^{37} \mathrm{Cl}_{\mathrm{EIL} 1}=+0.3 \%\right.$ and $\delta^{37} \mathrm{Cl}_{\mathrm{EIL} 2}=$ $-2.5 \%$ for PCE and $\delta^{37} \mathrm{Cl}_{\mathrm{EIL} 1}=+3.05 \%$ and $\delta^{37} \mathrm{Cl}_{\mathrm{EIL} 2}=$ $-2.70 \%$ 。 for TCE) which were formerly characterized by the Holt method (Holt et al., 1997) at the University of Waterloo was completed for each sequence to obtain $\delta$ values on the Standard Mean Ocean Chloride (SMOC) scale. Cl isotopic analysis of $c D C E$ was performed at Isotope Tracer Technologies Inc. (Waterloo) according to the method developed by Shouakar-Stash et al., 2006, using a Continuous Flow (CF) IRMS.

Molecular biology analysis: DNA extraction for the 454 pyrotag analysis was carried out at SiREM (Guelph, ON, Canada) as follows: Sterivex ${ }^{\mathrm{TM}}$ filters were opened and the filter membrane with attached biomass was removed and placed into the Bead Solution of a PowerMag DNA Isolation Kit 
(MoBio, Carlsbad, CA, USA) and pulverized using a sterile pipet tip. Cell lyses were performed using a MiniBeadbeater-8 (Biospec Products Bartlesville, OK, USA) at 50\% of the maximum setting for $30 \mathrm{~s}$. DNA was purified using a KingFisher ${ }^{\text {TM}}$ Duo (ThermoFisher Waltham, MA, USA) and eluted in $150 \mu \mathrm{L}$. DNA was quantified using a NanoDrop spectrophotometer (NanoDrop Inc. Wilmington, DE) and stored at $-80{ }^{\circ} \mathrm{C}$ after extraction. 16S rRNA genes were amplified from DNA extracts with universal primers $926 \mathrm{f}\left(5^{\prime}-\right.$ AAA CTY AAA KGA ATT GAC GG-3') and 1392r (5'-ACG GGC GGT GTG TRC-3') for 454 pyrotag analysis. The reverse primer also contained a 10 nucleotide barcode and 454 FLX Titanium Lib-L 'B' adapter. PCR was performed under the following conditions: $94{ }^{\circ} \mathrm{C}$ for $3 \mathrm{~min} ; 25$ cycles of $94{ }^{\circ} \mathrm{C}$ for $30 \mathrm{~s}, 52{ }^{\circ} \mathrm{C}$ for $30 \mathrm{~s}$, and $72{ }^{\circ} \mathrm{C}$ for $1 \mathrm{~min}$; and finally $72{ }^{\circ} \mathrm{C}$ for $10 \mathrm{~min}$. Amplicons were purified with GeneJET PCR Purification Kit (Life Technologies, Burlington, ON, Canada) and sequenced with Roche GS-FLX Titanium series kits and system (Roche, Branford, CT, USA) at Genome Quebec and McGill University Innovation Centre (Montreal, PQ Canada). Finally, analysis of the reads was performed using QIIME v.1.8 (Caporaso et al., 2010). Initially, raw reads were demultiplexed and filtered by quality (>Q20) and length (>250 nt) using the pick_otus.py script with usearch61 (Edgar et al., 2011) option and representative sequences were selected using the pick_rep_set.py. The sequences were aligned to the Greengenes Core reference alignment by PyNAST (Caporaso et al., 2010). Putative chimeric sequences were removed using ChimeraSlayer (Haas et al., 2011). Taxonomic assignment of the operational taxonomic units (OTU) was performed by assign_taxonomy.py script with the Ribosomal Database Project (RDP) method (Wang et al., 2007; Martins et al., 2013). A sequence was defined as belonging to a particular OTU when the similarity level was at least $97 \%$.

In order to evaluate which and to which extent microorganisms relevant to redox processes potentially occurring in the subsurface were present, OTU reads per sample were transformed to cells $\cdot \mathrm{L}^{-1}$ based on the total bacteria count (i.e. total DNA extracted from the samples). It was assumed that all the extracted DNA was prokaryotic, which leads to a slight overestimation, and that the average microbial genome contains $4 \cdot 10^{-6} \mathrm{ng} \mathrm{DNA} \cdot$ cell $^{-1}$ (Paul, 1996). Since chlorinated ethene degradation as well as redox processes occurring in the subsurface were of interest, detected microorganisms were grouped in taxonomic categories such as genera of which some strains are known to perform complete reductive dechlorination, partial reductive dechlorination of PCE and/or TCE, oxidation of $c$ DCE and or VC under aerobic conditions, bacteria reported to be found in iron- and sulfate-reducing conditions as well as during pyrite oxidation. Bacteria counts were then summed in each group and divided by the sum of bacteria counts of all targeted groups in each sample to evaluate the proportion of each bacteria group within each sample relative to the groups of interest. These data are summarised in Table $S$ 1 and Table S 2 of the Supporting Information (SI).

Dehalococcoides DNA and rRNA, bvcA and vcrA functional genes (DNA) and genes transcripts (mRNA) analysis was performed on co-extracted DNA and RNA using a combined phenol-chloroform and mechanical beadbeating method (Bælum et al., 2013). In brief: prior to cell lysis, the samples were mixed with $0.5 \mathrm{~mL}$ liquid G2 DNA/RNA enhancer (Ampliqon, Odense, Denmark) to cover binding sites of the clay particles. Extracted DNA and RNA was purified using NucleoSpin RNA Clean-up XS kit (Macherey-Nagel, Duren, Germany). RNA was converted to cDNA and DNA and cDNA PCR amplified using standard protocols with a detection limit of $10^{4}$ copies $\cdot \mathrm{L}^{-1}$. The detailed protocols can be found in the SI.

\subsection{Calculations for isotopic data interpretation}

\subsubsection{C isotope balance}

In order to evaluate isotopic data and more particularly to determine whether degradation released a significant amount of compounds which were not detected, such as ethene or ethane during complete sequential reductive dechlorination, the $C$ isotope balance was determined for each sampling point according to:

$\delta^{13} C_{\text {sum }}=\frac{[\mathrm{PCE}] \cdot \delta^{13} C_{\mathrm{PCE}}+[\mathrm{TCE}] \cdot \delta^{13} C_{\mathrm{TCE}}+[\mathrm{CDCE}] \cdot \delta^{13} C_{\mathrm{CDCE}}+[\mathrm{VC}] \cdot \delta^{13} C_{\mathrm{VC}}}{[\mathrm{PCE}]+[\mathrm{TCE}]+[\mathrm{CDCE}]+[\mathrm{VC}] .}$

where [PCE], [TCE], [CDCE] and [VC] are the molar concentrations of PCE, TCE, $C D C E$ and $\mathrm{VC}$, respectively, and $\delta^{13} C_{\mathrm{PCE}}$, $\delta^{13} C_{\mathrm{TCE}}, \delta^{13} C_{\mathrm{CDCE}}$, and $\delta^{13} C_{\mathrm{VC}}$ their corresponding $\mathrm{C}$ isotopic composition. The uncertainty was determined by error propagation (Reddy et al., 2002).

\subsubsection{Extent of degradation}

In order to estimate the extent of degradation in certain parts of the plume, the following coefficient was calculated:

$D=1-\exp \left(\frac{\Delta \delta^{13} C}{\varepsilon}\right)$

where $\Delta \delta^{13} \mathrm{C}$ corresponds to the difference between the initial and final $\mathrm{C}$ isotopic composition of the considered chlorinated ethene. Such calculation was performed only for compounds in sampling points where no precursor was present (e.g. for $c D C E$ when no PCE or TCE was detected) to ensure that the isotopic composition was merely affected by the compound degradation and not by its production. In the case of PCE, such caution is unnecessary as it can only be degraded. Minimum and maximum enrichment factors reported in the literature as well as a field determined enrichment factor were used as summarised in Table S3, SI.

\section{Results and discussion}

In this section, results from chemical, isotopic and molecular biology analyses are given and discussed with the aim to understand the effect of thermal remediation on the chlorinated ethene plume. Only the data from 27 screens of 13 wells which are located along the plume centreline are discussed.

\subsection{Redox conditions}

Concentrations of redox sensitive species measured in 2006 (Hunkeler et al., 2011) and 2014 are shown in Fig. 3A. In general, $\mathrm{O}_{2}$ and/or $\mathrm{NO}_{3}^{-}$concentrations larger than $1 \mathrm{mg} \cdot \mathrm{L}^{-1}$ are detected in the shallow top part of the aquifer (down to 10$15 \mathrm{~m}$ depth) whereas very low concentrations $\left(<0.1 \mathrm{mg} \cdot \mathrm{L}^{-1}\right)$ are found in deeper parts. Here, the presence of $\mathrm{Fe}$ (II) and/or 
methane indicates the occurrence of reducing conditions. Below $15 \mathrm{~m}$ depth, Concentrations of $\mathrm{SO}_{4}^{2-}$ range from 23 to $59 \mathrm{mg} \cdot \mathrm{L}^{-1}$ and are above $40 \mathrm{mg} \cdot \mathrm{L}^{-1}$, i.e. in the higher part of the concentration range. Based on the sulfur isotopic composition of $\mathrm{SO}_{4}^{2-}$, Hunkeler et al. suggested that the disappearance of $\mathrm{O}_{2} / \mathrm{NO}_{3}^{-}$and the increase of $\mathrm{Fe}(\mathrm{II}) / \mathrm{SO}_{4}^{2-}$ concentrations with depth could be associated with pyrite oxidation processes (Hunkeler et al., 2011), which is supported by the presence of pyrite in sandy aquifers in Jutland (Postma et al., 1991).

Unlike in 2006, in 2014, mixed redox conditions are generally observed at the local scale. Indeed, in 2014, markers for different redox conditions are simultaneously found within some screens (e.g. presence of $\mathrm{O}_{2}$ and $\mathrm{Fe}(\mathrm{II})$ in the same well). This might be explained by a certain subsurface heterogeneity that results in various redox zones overlaying each other within screen intervals ranging from 1 to $4 \mathrm{~m}$. Such a spatial change in redox conditions may result from the temporal change in redox conditions affecting geologically different layers at different speed. This temporal change is supported by the redox species evolution between 2004 and 2014 as depicted in Fig. 3 and is especially apparent in the first $750 \mathrm{~m}$ after the source where both $\mathrm{Fe}(\mathrm{II})$ and $\mathrm{O}_{2}$ are present. More particularly, the $\mathrm{NO}_{3}^{-}$ concentration suddenly drops $100 \mathrm{~m}$ downgradient from the source where $\mathrm{Fe}(\mathrm{II})$ concentrations increase right after the remediation event (Fig. 3), which indicates a shift toward more reduced conditions in 2014 compared to 2006 in the first $750 \mathrm{~m}$ of the plume (Fig. 3). A striking change directly following thermal remediation is the appearance of DOC in and downgradient of the source area that decreases over time (Fig. 3A and B16-1 in Fig. 3), presumably due to its transport and consumption. Although aquifers in this part of Jutland generally contain low levels of organic matter, high concentrations of DOC are measured immediately downgradient of the source area after the thermal remediation treatment, reaching values of $6.1 \mathrm{mg} \cdot \mathrm{L}^{-1}(\mathrm{~F} 3)$ and $3.1 \mathrm{mg} \cdot \mathrm{L}^{-1}(\mathrm{~B} 16$, located $100 \mathrm{~m}$ downgradient) in 2014. Such a release of sediment-bound organic matter due to thermal treatment has been previously reported near treated source areas (Newmark and Aines, 1995, Friis et al., 2005). Friis et al. confirmed via experiments performed with field material that up to $8 \%$ of sedimentbound organic carbon could be released in temperature conditions usually achieved with thermal treatments (Friis et al., 2005). Releasing organic matter can be expected to affect redox conditions. This is indeed observed immediately downgradient of the former source area (wells F2 and F3) where $\mathrm{O}_{2}\left(<1 \mathrm{mg} \cdot \mathrm{L}^{-1}\right)$ and $\mathrm{NO}_{3}^{-}$(up to $12.1 \mathrm{mg} \cdot \mathrm{L}^{-1}$ ) concentrations are much lower in 2014 than those measured in 2006 in nearby wells (B5, in the source and B11, $100 \mathrm{~m}$ downgradient), where concentrations of up to $5.2 \mathrm{mg} \cdot \mathrm{L}^{-1}$ and $28.0 \mathrm{mg} \cdot \mathrm{L}^{-1}$ for $\mathrm{O}_{2}$ and $\mathrm{NO}_{3}^{-}$were measured, respectively. The lower values measured in 2014 could be related to $\mathrm{O}_{2}$ and $\mathrm{NO}_{3}^{-}$ consumption during oxidation of organic matter. Additionally, the DOC content in B16, B20, B22, and B23, which are located up to $400 \mathrm{~m}$ downgradient of the source, was higher in 2010 (Westergaard et al., 2011) than in 2014, supporting the gradual consumption of DOC released by the thermal treatment. Concomitantly, depletion in $\mathrm{O}_{2}$ was generally observed in $\mathrm{B} 16$ B20 B22 B23 and B28 in 2010 (Westergaard et al., 2011) compared to 2014, which coincides with DOC consumption leading to more reduced conditions. The significant change in $\mathrm{Fe}(\mathrm{II})$ and $\mathrm{SO}_{4}^{2-}$ concentrations observed between 2006 and
2014 in the upper part of the aquifer from the source zone to $750 \mathrm{~m}$ downgradient could also be attributed to the oxidation of organic matter released from remediation, which consequently led to more reduced conditions and temporal lack of pyrite oxidation due to lack of oxygen. Indeed, higher Fe(II) concentrations $\left(>1 \mathrm{mg} \cdot \mathrm{L}^{-1}\right)$, especially in the shallow part and in $\mathrm{B} 28$, as well as slightly lower $\mathrm{SO}_{4}^{2-}$ concentrations are observed in this part, indicating more reduced conditions. Such a DOC impact leading to more reduced conditions is particularly reflected by B16-1 (Fig. 3). High DOC and $\mathrm{SO}_{4}^{2-}$ concentrations (probably due to pyrite oxidation due to steam injection saturated with air) were indeed observed right after remediation in this sampling point, where less concentrated $\mathrm{NO}_{3}^{-}$and $\mathrm{O}_{2}$ concentrations (due to DOC oxidation) were concomitantly observed. The DOC concentration then gradually decreased (B16-1 in Fig. 3). Another striking change between 2006 and 2014 is the lack of Fe(II) detected in 2014 between 1000 and $1500 \mathrm{~m}$ downgradient from the source (wells B34, B47 and B58). In these wells, concentrations of methane increased whereas $\mathrm{SO}_{4}^{2-}$ concentrations showed up to 20\% decrease in 5 out of 8 sampling points, which suggests the occurrence of $\mathrm{SO}_{4}^{2-}$ reduction followed by the precipitation of metastable iron sulphide or $\mathrm{Fe}$ (II) binding to other minerals. This suggests that the DOC release affected this part of the aquifer too as the flowline descends where the clay layer observed under the source area disappears. The occurrence of sulfate-reducing conditions in this part of the plume would be additionally favorable for chlorinated ethene microbial reductive dechlorination, especially of $C$ DCE and VC (Vogel et al., 1987; Chapelle, 1996). At the fringe of the plume (i.e. $>1800 \mathrm{~m}$ from the source), concentrations of $\mathrm{Fe}(\mathrm{II})$ increased in 2014 compared to 2006 ( $>1 \mathrm{mg} \cdot \mathrm{L}^{-1}$ ) and methane is detected in B64, which indicates more strongly reduced conditions in 2014 than in 2006.

\subsection{Evolution of chlorinated ethene concentrations}

The distribution of individual chlorinated ethenes was evaluated in a vertical section along the plume centerline before (2006, Hunkeler et al., 2011) and eight years after (2014) performing the thermal source remediation (Fig. 4). In both cases, in the first $350 \mathrm{~m}$ from the source, the contaminant plume is confined in the upper part of the aquifer due to the presence of a clayey layer at $20 \mathrm{~m}$ depth. Further downgradient, the plume widens and dives toward deeper zones while exhibiting more reduced conditions, as discussed above. The remediation primarily resulted in a dramatic drop in chlorinated ethene concentration immediately downgradient.

In 2014, a strong decrease in PCE, TCE and CDCE concentrations of more than $85 \%$ is observed in wells immediately downgradient (i.e. wells F2, F3 and F4, Fig. 2) between 2006 and 2014. Much lower concentrations are also generally measured in wells situated within $750 \mathrm{~m}$ from the source in 2014 compared to 2006, with the exception of higher values obtained for TCE at the bottom of B23 (e.g. $1.1 \mu \mathrm{mol} \cdot \mathrm{L}^{-1}$ in 2014 instead of $0.43 \mu \mathrm{mol} \cdot \mathrm{L}^{-1}$ in 2006). Further downgradient, lower concentrations are generally found for PCE and TCE, which eventually disappear $1050 \mathrm{~m}$ (PCE) and 1450 m (TCE) downgradient. Similarly, cDCE concentrations decreased $1050 \mathrm{~m}$ downgradient of the source in 2014 compared to $1050 \mathrm{~m}$ downgradient of the source in 2006 . The 

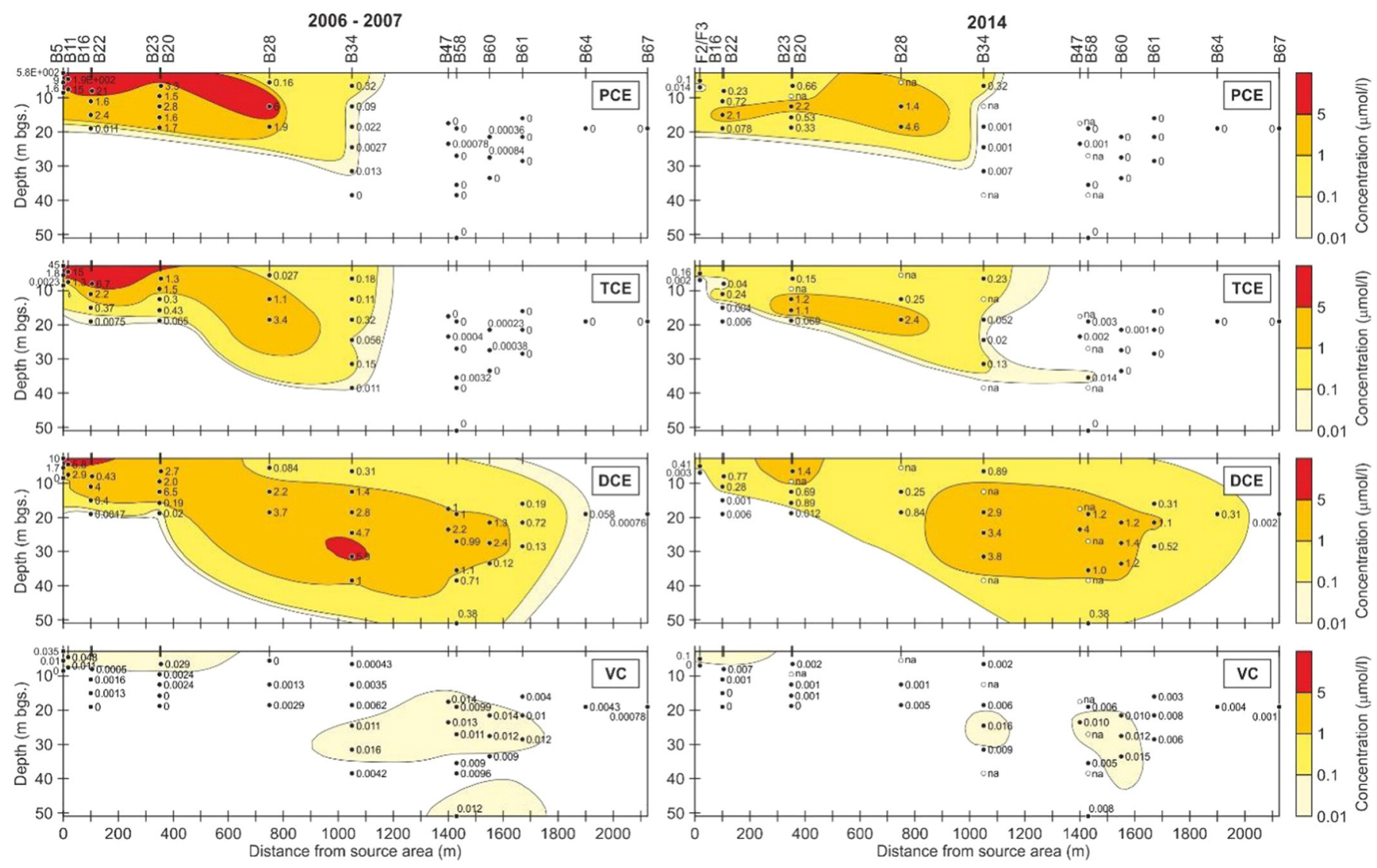

Fig. 4. Chlorinated ethene concentration in the subsurface in 2006 (Hunkeler et al., 2011) and 2014 (this study). 

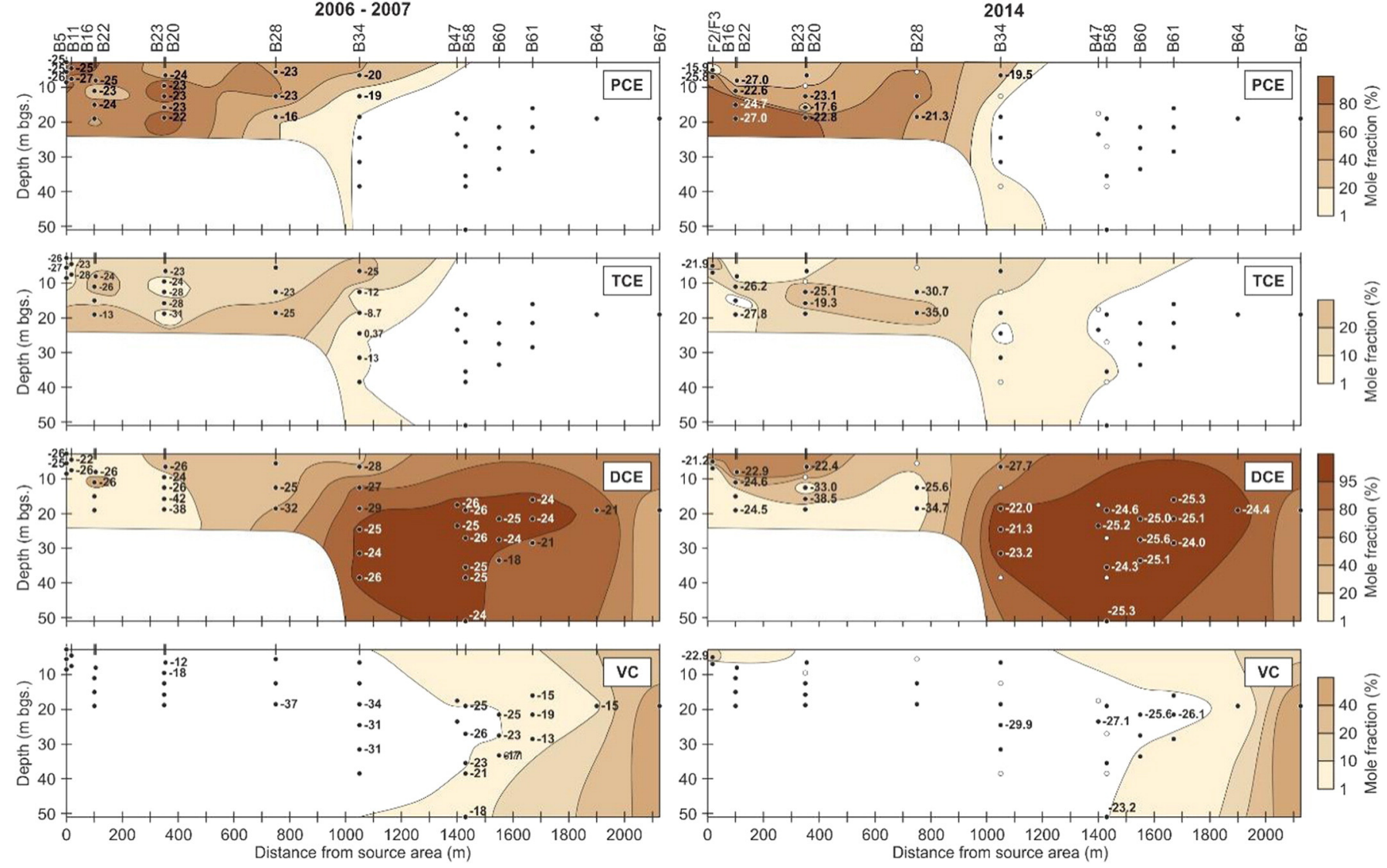

Fig. 5. Mole fractions and C isotopic composition of chlorinated ethenes before (2006, Hunkeler et al., 2011) and after (2014) source thermal treatment. 
most pronounced change in chlorinated ethene composition in terms of concentrations and species proportions occurs as the plume crosses the pyrite oxidation boundary depicted in Fig. 11, zone 3. However, an increase in the CDCE concentration at the plume front $(>1550 \mathrm{~m}$ ) together with a plume front that extends further downgradient in 2014 compared to 2006 indicates that $c D C E$ accumulates in this area and is still slowly expanding, as depicted by the difference in concentration contours in Fig. 4. Considering the high overall groundwater velocity of $\sim 0.24 \mathrm{~m} \cdot \mathrm{day}^{-1}$, the almost identical plume length indicates that the overall effect of natural attenuation is nonetheless similar between 2006 and 2014. The highest mole fractions of VC (up to 40\% in B67) are determined in this part of the aquifer (Fig. 5) although VC concentrations are lower in 2014 than in 2006. Contrary to 2006, when the highest concentration of chlorinated ethenes was detected in the source area, the high concentration core of the plume is now located around $750 \mathrm{~m}$ to $1450 \mathrm{~m}$ downgradient.

From the source zone to $750 \mathrm{~m}$ downgradient, PCE is generally the predominant chlorinated ethene in the lower part of the plume in 2014; its concentration reaches more than $85 \%$ of the total chlorinated ethene concentration on a molar basis at the bottom of wells B22 and B23 (Fig. 5). On the other hand, the mole fraction of $c D C E$ dominates in the upper part of the plume within $350 \mathrm{~m}$ from the source where mole fractions reach up to $74 \%$. The change in chlorinated ethene distribution between 2006 where PCE was the predominant chlorinated ethene in the first $750 \mathrm{~m}$ of the plume and 2014 suggests the occurrence of biotic reductive PCE/TCE dechlorination. Such an occurrence is additionally supported by higher DOC concentrations and more strongly reduced conditions observed in 2014 compared to 2006 in this part of the plume. In contrast to the part of the plume immediately downgradient from the source where PCE dominates, $c D C E$ is the predominant chlorinated ethene further downgradient (i.e. $>750 \mathrm{~m}$ ).

During biotic reductive dechlorination, PCE can be transformed via sequential hydrogenolysis to ethene (i.e. $\mathrm{PCE} \rightarrow \mathrm{TCE} \rightarrow \mathrm{cDCE} \rightarrow \mathrm{VC} \rightarrow$ ethene). Yet, VC and ethene are here either detected at trace levels (VC) or not detected (VC and ethene), which suggests that $\mathrm{CDCE}$ transformation is the rate limiting step if it is primarily degraded by biotic reductive dechlorination. Abiotic reductive dechlorination of PCE, TCE

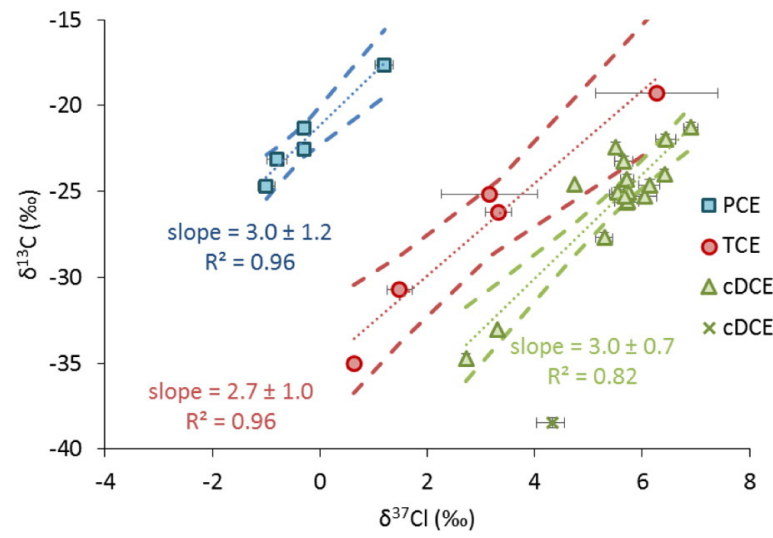

Fig. 6. Dual $\mathrm{C}-\mathrm{Cl}$ isotope slopes associated with PCE, TCE and $c D C E$. One $\mathrm{C}-\mathrm{Cl}$ isotopic composition of $c$ DCE which did not align with the others is represented separately as a cross. Slopes are given with $95 \%$ confidence interval. and $c$ DCE by pyrite which bears Fe(II) could also contribute to their attenuation (Lee and Batchelor, 2002a). In this case, transformation of PCE, TCE and $C D C E$ generally leads to formation of acetylene as the main intermediate via $\beta$ dichloroelimination. Although acetylene was not detected in the aquifer, the additional occurrence of abiotic reductive dechlorination cannot be overlooked as acetylene can be further transformed to readily biodegradable compounds such as acetaldehyde, acetate and ethanol in groundwater (Liang et al., 2009). Finally, while biotically produced mackinawite may catalyze abiotic reductive dechlorination of PCE and TCE (Butler and Hayes, 1999), it was shown that $c$ DCE was not reactive with mackinawite (Jeong et al., 2011). Abiotic reductive $c D C E$ dechlorination is thus not likely to take place in the presence of mackinawite, though biotically produced nonmeasurable surface-bound Fe(II) (Han et al., 2012) and other reduced iron minerals such as green rust (Lee and Batchelor, 2002b) may induce such a reaction.

\subsection{Chlorinated ethene $\mathrm{C}$ and $\mathrm{Cl}$ isotopic composition}

Chlorinated ethene concentrations and isotopic compositions measured in 2014 are summarised in Table S3, SI.

The $C$ isotopic ratio of released PCE was formerly estimated to be $-25.0 \%$ (Hunkeler et al., 2011). The $\mathrm{Cl}$ isotope measurements performed in 2014 show a lowest $\delta^{37} \mathrm{Cl}$ value of $-1.0 \%$ for PCE at 100 and $750 \mathrm{~m}$ downgradient from the source, which is the closest measured value to the initial $\mathrm{Cl}$ isotope signature of released PCE. Without further data, the initial PCE isotopic signature is hence assumed to be $\delta^{13} \mathrm{C}=$ $-25.0 \%$ and $\delta^{37} \mathrm{Cl}=-1.0 \%$.

In 2014, apart from two sampling points located $100 \mathrm{~m}$ downgradient from the source, PCE C isotopic values are generally more enriched in ${ }^{13} \mathrm{C}$ than the initial isotopic signature, reaching up to $-19.5 \%$ o in B34-6 (Fig. 5), which clearly indicates that PCE degradation is occurring in the plume. On the other hand, TCE C isotopic values exhibit a higher spatial variability. The sampling points in the source area up to $350 \mathrm{~m}$ downgradient show $\mathrm{C}$ isotopic compositions varying from -27.0 to $-19.3 \%$ o (Fig. 5), which indicates the occurrence of TCE degradation. Conversely, $750 \mathrm{~m}$ downgradient, values of $-30.7 \%$ o to $-35.0 \%$ indicate that if TCE is undergoing further degradation, this process is either limited or slower than TCE production from PCE. The $\mathrm{Cl}$ isotopic values of PCE and TCE are coherent with their respective $C$ isotopic values: the highest values, which reflect enrichment in ${ }^{37} \mathrm{Cl}$, are found where higher $C$ isotopic values are detected. (e.g. B23-2 for PCE and TCE, B22-3 for TCE, Table S3, SI). This additional line of evidence points toward the occurrence of degradation in these sampling points (between the source and $350 \mathrm{~m}$ downgradient).

C isotopic ratios of $c$ DCE vary from $-38.5 \%$ (B23-2, $350 \mathrm{~m}$ downgradient) to $-21.3 \%$ 。(B34-3, $1050 \mathrm{~m}$ downgradient). Isotopic values enriched in ${ }^{13} \mathrm{C}$ compared to the assumed initial PCE isotopic signature of $-25.0 \%$ are found in the source zone up to $350 \mathrm{~m}$ downgradient in the upper part of the aquifer, as well as $1050 \mathrm{~m}$ downgradient. This suggests that $\mathrm{CDCE}$ is being degraded in these parts of the aquifer. Lower $C$ isotopic values found in the deeper part of the aquifer $350 \mathrm{~m}$ to $750 \mathrm{~m}$ from the source area indicate that if $c D C E$ is being degraded, this process is either limited or slower than CDCE production from TCE. Contrary to 2006, when C isotopic values of $C D C E$ and VC 
reached up to $-18 \%$ and $-13 \%$, respectively, at the plume front $(>1400 \mathrm{~m})$, such enriched values are not observed in the same part of the plume in 2014, when C isotopic values of $c$ DCE and VC reached up to $-24.0 \%$ and $-23.2 \%$, respectively. This suggests that $C D C E$, or VC when it is present, experiences less degradation. These lower values could also be attributed to the influx of the less degraded cDCE present $1050 \mathrm{~m}$ downgradient from the source in 2006. Moreover, VC is generally almost not depleted in comparison to $\mathrm{CDCE}$, which contradicts all trends of $\mathrm{C}$ isotope ratios observed in all biodegradation studies to date (Bloom et al., 2000; Slater et al., 2001; Abe et al., 2009; Fletcher et al., 2011). Such little difference in $C D C E$ and VC isotopic composition could however reflect the occurrence of abiotic cDCE degradation rather than biotic degradation. Indeed, this is consistent with studies on abiotic chlorinated ethene degradation (Elsner et al., 2008; Audí-Miró et al., 2013) where VC and acetylene were formed in parallel and where isotopically sensitive branching lead to the unexpected situation where VC was scarcely depleted compared to its precursor. The most ${ }^{13} \mathrm{C}$ enriched values for $\mathrm{CDCE}$ are found $1050 \mathrm{~m}$ downgradient of the source as well as close to the source, indicating a stronger degradation activity in these areas than in the rest of the aquifer. While single element isotopic analysis enables identification of areas where degradation is taking place, it does not permit differentiation between various processes governing degradation, except in the case of $c D C E$ where the data point toward abiotic degradation.

Dual $\mathrm{C}-\mathrm{Cl}$ isotope slopes may provide additional insight into such processes (Abe et al., 2009; Elsner, 2010; Cretnik et al., 2013; Kuder et al., 2013) although limitations were recently pointed out (Badin et al., 2014; Renpenning et al., 2014). For PCE, the dual $\mathrm{C}-\mathrm{Cl}$ isotope slope of $3.0 \pm 1.2$ associated with data points located between the source area and 750 downgradient falls within the range reported for microbial reductive dechlorination in field studies (0.7-3.5) and in laboratory experiments (0.7-2.7) (Badin et al., 2014) (Fig. 1 and Fig. 6). Since no dual $\mathrm{C}-\mathrm{Cl}$ slope for abiotic PCE reduction has been reported so far, no comparison is possible. These observations thus constitute an additional line of evidence that supports the likeliness that PCE undergoes biotic reductive dechlorination in the first $750 \mathrm{~m}$ of the plume.

The dual $\mathrm{C}-\mathrm{Cl}$ isotope slope of $2.7 \pm 1.0$ observed for TCE for sampling points located between the source area and $1050 \mathrm{~m}$ downgradient cannot be compared to reported ranges of dual isotope slopes associated with sole TCE degradation in a way as straightforward as for PCE since here TCE is both produced and consumed. It was previously shown that the dual isotope slope associated with a both produced and degraded chlorinated ethene was controlled by its degradation when this step was rate-limiting, i.e. when an accumulation of this intermediate compound was observed (Hunkeler et al., 2009). TCE accounts for up to $30-40 \%$ at 350 and $750 \mathrm{~m}$ downgradient from the source, which suggests that it accumulates before becoming further degraded to $\mathrm{CDCE}$. It can thus be assumed that the dual isotope slope associated with TCE in this part of the plume is controlled by TCE degradation and may be compared with slopes associated with biotic reductive TCE dechlorination. When taking the uncertainty of \pm 1.0 into account, the TCE dual C- $\mathrm{Cl}$ isotope slope observed in Rødekro is not significantly different from the range observed for biotic reductive TCE dechlorination (3.4-4.8, Cretnik et al., 2013;
Kuder et al., 2013), but is significantly different from the slope obtained for abiotic TCE reduction ( $5.2 \pm 0.3$, Audí-Miró et al., 2013). These observations support the occurrence of biotic reductive TCE dechlorination in this part of the plume.

The formerly reported dual $\mathrm{C}-\mathrm{Cl}$ isotope slope of 2.1 (published $\varepsilon_{\mathrm{Cl}} / \varepsilon_{\mathrm{C}}=0.48 \pm 0.05$, Hunkeler et al., 2011) associated with $c$ DCE from data points located $1050 \mathrm{~m}$ downgradient of the source to the plume front was at the time compared with slopes associated with biotic reductive cDCE dechlorination (11.4 to 13.7 , published $\varepsilon_{\mathrm{Cl}} / \varepsilon_{\mathrm{C}}=0.088 \pm$ 0.004 to $0.073 \pm 0.006$ ). It was thus concluded based on the dual isotope approach that $c D C E$ was either reductively dechlorinated by other strains than those previously studied or that abiotic degradation occurred. Audi-Miro et al. recently reported a dual $\mathrm{C}-\mathrm{Cl}$ isotopic slope of $3.1 \pm 0.2$ associated with abiotic reductive $c$ DCE dechlorination (Audí-Miró et al., 2013). The slope value observed in Rødekro in 2006 was closer to the one observed for abiotic reductive $C D C E$ dechlorination than to those associated with biotic reductive dechlorination. A slope of $1.5 \pm 0.2$ associated with $C D C E$ degradation that occurred by simultaneous biotic and abiotic reductive dechlorination in the subsurface in the presence of a permeable reactive barrier containing 3\% (v/v) zero-valent Fe was more recently reported (Audí-Miró et al., 2015). Although Audi-Miro et al. concluded that abiotic reduction was not the predominant degradation process, it cannot be disregarded that this slope is influenced by the latter. $c$ DCE was thus likely to be abiotically reduced by pyrite (and/or other reduced iron minerals) in the sediment in 2006 between $1050 \mathrm{~m}$ downgradient of the source and the plume front although acetylene (degradation product of abiotic dihaloelimination) was not detected. In 2014, except for one point (B23-3), C-Cl isotope data align with generally less enriched values closer to the source and more enriched values further downgradient to generate a slope of $3.0 \pm 0.7$ $\left(\mathrm{R}^{2}=0.82\right)$. This slope is within the $95 \%$ confidence interval of the slope of $3.1 \pm 0.2$ associated with abiotic $c$ DCE degradation determined by Audi-Miro et al. (Audí-Miró et al., 2015) (Fig. 6 and Table S 3, SI). This supports the predominance of abiotic cDCE reduction in the core of the plume in 2014 as also indicated by the $\mathrm{C}$ isotopic data. Without the evidence brought forward by isotopic data, the presence of VC could be attributed to $\mathrm{CDCE}$ hydrogenolysis. However the little VC ${ }^{13} \mathrm{C}$ depletion compared to $C D C E{ }^{13} \mathrm{C}$ depletion suggests that VC may rather be produced during abiotic $c$ DCE degradation, as previously observed by Elsner et al., 2008 and Audi-Miro et al., 2013.

Apart from immediately downgradient of the source area, where the VC C isotopic composition is $-22.9 \%$, and at the deepest sampling point in B58, the VC C isotopic composition does not become much more enriched than the assumed initial isotopic signature of PCE $(-25.0 \%$ \%). It is therefore unlikely that further hydrogenolysis of VC to ethene takes place despite more optimal redox conditions for reductive VC dechlorination in 2014 than in 2006 (i.e. sulfate-reducing, Chapelle, 1996). Finally, while anaerobic oxidation was suggested as a possible degradation pathway (Smits et al., 2011), the likeliness of such a process to occur remains unclear. Gossett et al. previously suggested that what was in microcosms thought to be anaerobic oxidation might actually be aerobic oxidation with $\mathrm{O}_{2}$ concentrations so low that $\mathrm{O}_{2}$ is quickly consumed and not measurable (Gossett, 2010). However, based on the current data, anaerobic or microaerophilic oxidation cannot be ruled 


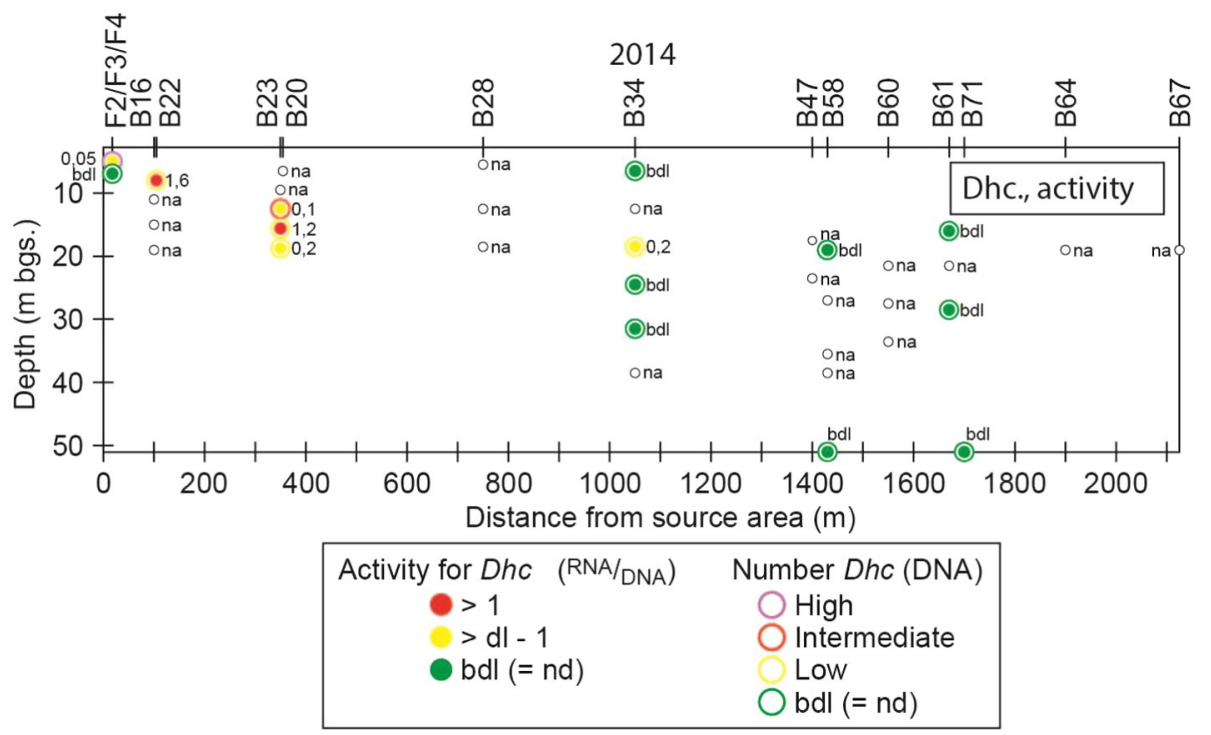

Fig. 7. Dhc population size and activity in the subsurface. Given values correspond to the ratio rRNA/DNA. High $>1 \cdot 10^{6}$ gene $\operatorname{copies} \cdot \mathrm{L}^{-1}$; Intermediate $\in\left[3 \cdot 10^{5}-1 \cdot 10^{6}\right]$ gene copies $\cdot \mathrm{L}^{-1}$; Low $\in\left[\mathrm{bdl}-3 \cdot 10^{5}\right]$ gene copies $\cdot \mathrm{L}^{-1}$. na: not analysed. dl: detection limit. Bdl: below detection limit. nd: not detected.

out. Moreover, the conditions are not aerobic in this part of the aquifer, which means aerobic oxidation is not possible.

The highest $\delta^{13} C_{\text {sum }}$ value at the site $(-21.3 \%$ in B34-3, Table S 3, SI) indicates a maximum enrichment in ${ }^{13} \mathrm{C}$ of $3.7 \%$. This also supports the supposition that limited transformation of chlorinated ethenes to non-toxic compounds, such as ethene, is occurring, unless it is via a degradation process associated with low isotopic fractionation.

Dual $\mathrm{C}-\mathrm{Cl}$ isotope slopes convey even more valuable information. Hunkeler et al., 2009 predicted that the vertical spacing between dual isotope slopes associated with chlorinated ethenes during reductive dechlorination reflected the $\mathrm{C}$ enrichment factors when the slopes run parallel to each other. The reason is that the kinetic $\mathrm{Cl}$ isotope effect acts on the cleaved chloride so that the chlorine isotope ratio of TCE is expected to match that of PCE (as experimentally confirmed by Cretnik et al., 2014), whereas $C$ isotope values differ by the $C$ enrichment factor $\varepsilon_{c}$. Here, a $C$ enrichment factor of $-10.3 \%$ may be determined when subtracting the $C$ isotope value of the most depleted $\mathrm{PCE} C-\mathrm{Cl}$ signature (corresponding to the initial PCE signature) from the most depleted TCE $\mathrm{C}-\mathrm{Cl}$ signature (where the $\mathrm{Cl}$ isotope value is the closest to that of the initial PCE signature). On the other hand, interpreting the spacing between TCE and $\mathrm{CDCE}$ is less straightforward as it is also influenced by the intramolecular chlorine isotope distribution in TCE.

In order to determine the extent of degradation of PCE and cDCE in some sampling points, minimum and maximum enrichment factor values reported in the literature were chosen since no microcosm experiment was carried out based on which site specific enrichment factors could be determined. The estimation of the extent of PCE degradation based on C isotopic data is an exception where the $C$ enrichment factor determined above was used. As the data support biotic reductive PCE dechlorination and abiotic $c$ DCE reduction, corresponding enrichment factors were chosen. The extent of degradation, $\mathrm{D}$, was determined both with $\mathrm{C}$ and $\mathrm{Cl}$ isotope data. Results can be found in Table S 3, SI. For PCE, the extent of degradation determined with the $C$ enrichment factor varies from 3 to $59 \%$ with an average of $28 \%$. This is in agreement with the average extent of degradation determined with largest and smallest $\mathrm{Cl}$ enrichment factors associated with reductive PCE dechlorination of 10 and 34\%, respectively. The estimated extent of degradation based on $\mathrm{C}$ and $\mathrm{Cl}$ data are moreover consistent for each sampling point. Finally, for abiotic reductive cDCE dechlorination, average extents of degradation of 7 and $19 \%$ could be determined based on the largest and smallest enrichment factors associated with this degradation process, respectively. This is in agreement with the observed degradation stall at $c \mathrm{DCE}$.

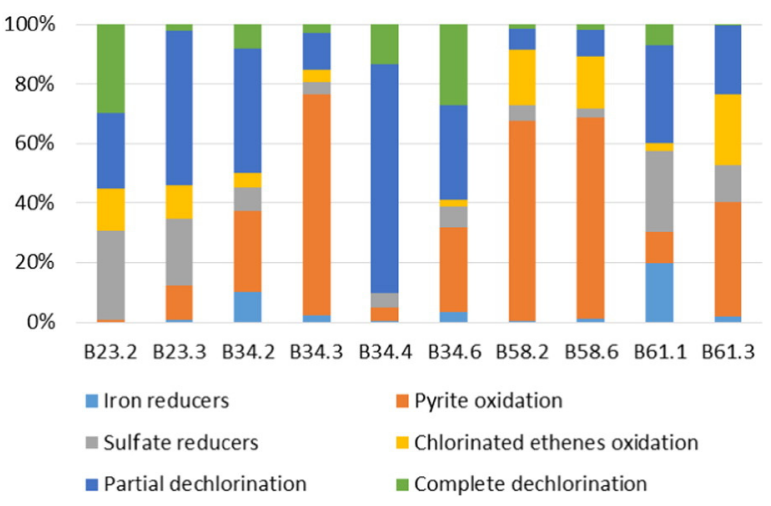

Fig. 8. Relative proportion of bacteria which have been identified to belong to a $16 S$ rRNA gene based phylogenetic group that has been shown to contain bacteria involved in iron-reduction, sulfate-reduction, partial dechlorination, pyrite oxidation, biotic chlorinated ethene oxidation or complete dechlorination processes. Only these phylogenetic groups (Table S 5, SI) are included in the analysis. 


\subsection{Input from molecular biology}

454 pyrotag sequencing, Dhc DNA and mRNA, bvcA and vcrA functional genes, and gene transcript (mRNA) analyses were performed to acquire complementary information to understand the processes affecting chlorinated ethenes in the aquifer after the source thermal remediation.

The total Dhc population analysis performed by qPCR shows a relatively large range across sampling wells from not detected (below detection limit, bdl) to $1.73 \cdot 10^{6}$ gene copies $\cdot \mathrm{L}^{-1}$ (Fig. 7 and Table S 4, SI). Higher abundances are measured from the source area to $350 \mathrm{~m}$ downgradient while lower abundances to non-detects are measured from $1050 \mathrm{~m}$ downwards except in B34-4 where intermediate quantities of $1.03 \cdot 10^{5}$ gene copies $\cdot \mathrm{L}^{-1}$ are detected. Only a few sampling locations (i.e. F4-3, B16-1, B17-1, B23-1, B23-2, B23-3, and B34-4) indicate Dhc quantities in the ranges previously reported for other sites where biotic reductive dechlorination has naturally occurred (Damgaard et al., 2013b) (from $10^{5}$ to $10^{6}$ gene copies $\mathrm{L}^{-1}$, Table S 4, SI) and are thus high enough to support some dechlorination potential. Yet, the detection of Dhc DNA is not sufficient to confirm the actual occurrence of dechlorination as DNA does not indicate bacterial activity. On the other hand, Dhc targeted rRNA is detected up to $2.48 \cdot 10^{5}$ copies $\cdot \mathrm{L}^{-1}$ in sampling points located between the source zone to $1050 \mathrm{~m}$ downgradient (Table S4, SI). Relatively higher proportions of 16S rRNA than corresponding DNA in wells B16-1 and B23-2 compared with other wells indicate that Dhc in B16-1 and B232 are more metabolically active than $D h c$ in some other locations. Although rRNA/DNA ratios in B16-1 and B23-2 are not much higher than 1 (max. ratio: 1.56 ), Dhc activity was previously associated with ratios of this order of magnitude in a previous laboratory study (Wagner et al., 2013). The presence and apparent high activity of Dhc in B16-1 and B23-2 coincide with highly enriched $C$ isotope ratios of $-17.6 \%$ for PCE and $-19.3 \%$ for TCE in B23-2 and $-22.9 \%$ for $c$ DCE in B16-1 (Fig. 5, Fig. 7, Table S3 and Table S4, SI).

Genes coding for the enzymes involved in the final transformation of $\mathrm{VC}$ to ethene ( $v c r A$ and $b v c A)$ are neither present (DNA) nor expressed (mRNA) above the detection limit. This is consistent with the minor $C$ isotopic enrichment observed for VC, which supports an absence of VC degradation by reductive dechlorination at the site. Nevertheless, further reductive $\mathrm{VC}$ dechlorination cannot be ruled out as VC rdhA genes other than $v c r A$ and $b v c A$ may exist. It was indeed recently demonstrated that some members of the Dehalogenimonas (Dhg) genus respire VC and thus participate in VC dechlorination to ethene (Yang and Löffler, 2015).

Pyrotag sequencing enabled the identification of the relative abundance of various bacteria in the sampled locations (Fig. 8 and Table S5, SI). As only specific groups are targeted (i.e. iron-, sulfur-reducing, pyrite oxidizing, chlorinated ethene oxidizing, chlorinated ethene complete and partial reductive dechlorinators), other groups of bacteria which may be present in some samples, such as aerobic samples, do not appear. In the absence of $\mathrm{O}_{2}$ and $\mathrm{NO}_{3}^{-}$, such bacteria may use iron as an electron acceptor, thus acting as an iron-reducer although it is not included among the list of iron-reducers established in this study. Based on pyrotag sequencing data, relative proportions to the sample with highest bacteria quantity of various bacteria involved in redox processes (Fig. 9) and in chlorinated ethene

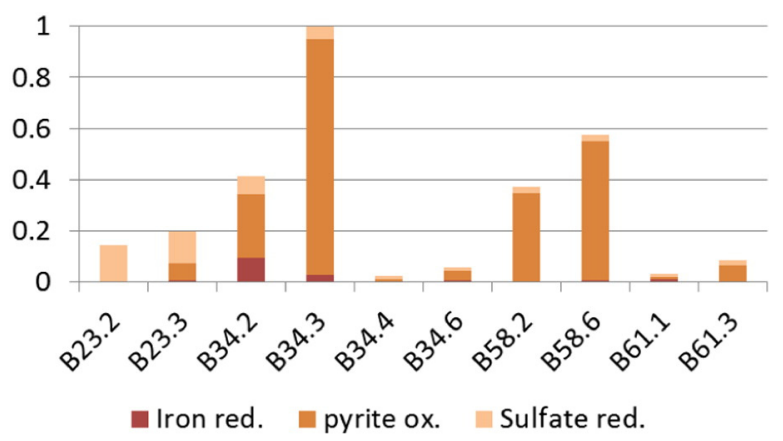

Fig. 9. Proportion of bacteria that have been identified to belong to a 16S rRNA gene based phylogenetic group that has been shown to contain bacteria involved in sulfate-reduction, iron-reduction and pyrite oxidation normalized by the maximum total quantity of bacteria involved in such redox processes among all samples.

bioremediation (Fig. 10) could also be determined. Generally, low relative abundance (ranging from 0 to $4 \%$ ) is found in all samples for bacteria likely involved in iron reduction among all of the considered groups (i.e. bacteria involved in iron- and sulfate-reduction, pyrite oxidation, chlorinated ethene oxidation, and partial and complete reductive dechlorination) (Fig. 8 and Table S5, SI), which coincides with the relatively reduced conditions observed in most of the aquifer based on redox species concentrations. Bacteria reported to be present in sulfate-reducing conditions ( 4 out of 10 wells where the relative proportion is $>10 \%$ ) as well as during pyrite oxidation ( 6 out of 10 wells where the relative proportion is $>26 \%$ ) are detected in high relative abundance (Table S5 and Fig. 8, SI), which corroborates the redox data and indicates a high likelihood of pyrite oxidation and sulfate-reducing conditions. More specifically, bacteria reported to be involved in pyrite oxidation are found in relative abundance higher than $20 \%$ in B34-2, B34-3, B34-6, B58-2, B58-6 and B61-3, i.e. from $1050 \mathrm{~m}$ downgradient of the source. This coincides with $C D C E$ dual $\mathrm{C}-\mathrm{Cl}$ isotope data that suggests abiotic $\mathrm{CDCE}$ reduction predominates in these locations. Bacterial genera among which some members are known to catalyze complete reductive dechlorination of chlorinated ethene (i.e. Dhc, Löffler et al., 2013, and Dhg, Yang and Löffler, 2015) are

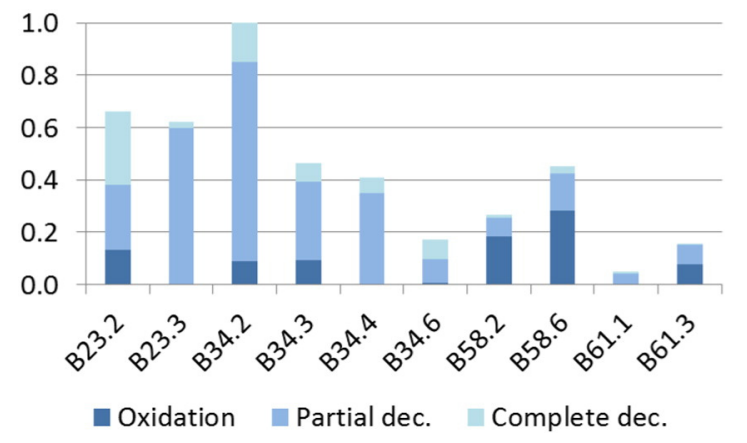

Fig. 10. Proportion of bacteria that have been identified to belong to a $16 \mathrm{~S}$ rRNA gene based phylogenetic group that has been shown to contain bacteria involved in biotic chlorinated ethene oxidation, and partial or complete dechlorination processes normalized by the maximum total quantity of bacteria involved in chlorinated ethene bioremediation processes among all samples. 
detected in the majority of sampling locations (Fig. 8). In particular, the relative abundance of bacteria potentially able to completely dechlorinate chlorinated ethene is high in B23-2 (350 m downgradient) and B34-6 (1050 m downgradient), indicating the possibility that complete reductive dechlorination may have occurred in these locations. The counts of Dhc from pyrotag sequencing do not exactly coincide with the copy number of Dhc determined by targeted quantitative PCR after DNA extraction (Table S 4 and Table S 5, SI), which may be because 454 pyrotag sequencing is considered a semi-quantitative method and different amplification primers were used. Contrary to Dhc, Dhg is detected in all samples, and reads are particularly high in B23-2 $\left(1.7 \cdot 10^{6}\right.$ cells $\cdot \mathrm{L}^{-1}$, Table S5, SI). Among the bacterial genera among which some members are known to reduce chlorinated ethenes only partially, several are detected in particular in B23-3, B34-2, B34-4, 34-6 and B61-1 (Fig. 8 and Table S5, SI), which indicates that bacteria potentially able to dechlorinate chlorinated ethenes are present throughout the entire plume. Finally, highest quantities of partially and totally dechlorinating bacteria are found in B23-2, B23-3 and B34-2 (Fig. 10), which supports the higher likeliness that biotic reductive dechlorination is occurring in the first part of the plume. The highest proportions of bacteria involved in pyrite oxidation are found from the core to the front of the plume (B34-2, B34-3, B58-2 and B58-6, Fig. 9), which supports the predominant occurrence of abiotic chlorinated ethene reduction in this part of the plume.

Generally, the molecular biology data suggests that reductive dechlorination could potentially occur in any sampling location, with a higher likelihood in B16-1, F4-3 (which are located immediately downgradient from the source), B23-2 and B34-4 (which are located 350 and $1050 \mathrm{~m}$ downgradient from the source). Moreover, it cannot be definitively determined whether complete degradation is possible because neither bvcA nor vcrA genes were detected.

Pyrotag sequencing data also highlight the possibility that $c D C E$ and/or VC may have been oxidized, especially downgradient (from B58 to B61) where Polaromonas reads are the highest (Table S 5, SI). However, this is more plausible in the upper rather than deeper parts of the aquifer, where oxic conditions are unlikely.

\section{Summary of redox and chlorinated ethene degradation processes occurring in the aquifer from 2006 to 2014}

Drawings that describe redox and chlorinated ethene degradation processes that likely occurred in the subsurface in 2006 and 2014 and the consequences of these processes on chlorinated ethene distribution in the plume are given in Fig. 11. These models result from the combination of lines of evidence brought by the different methods applied in this study (i.e. redox conditions, contaminant concentration, isotope analysis and molecular biology).

\subsection{First $750 \mathrm{~m}$}

Based on the performed investigations, it was confirmed that PCE and TCE are very likely dechlorinated by biotic reductive dechlorination in the upper part of the plume, in the first 350 to $750 \mathrm{~m}$ downgradient from the source, either due to the former presence of hydrocarbons (2006) and natural influx of low background DOC or to the release of DOC during thermal remediation (2014). Redox conditions are generally more reduced in the source area in 2014 than in 2006 due to the DOC release. $C D C E$ is the dominant chlorinated ethene immediately downgradient of the source in 2014 as a result of biotic reductive PCE and TCE dechlorination occurring in more reduced conditions. Biotic reductive dechlorination of $c \mathrm{DCE}$ also likely occurs but to a lesser extent, and both $C D C E$ and VC may be biotically oxidized in the upper part of the aquifer shortly downgradient of the source where aerobic conditions are present.

\subsection{0 to $900 \mathrm{~m}$ downgradient}

As the plume moves forward, it dips and enters a more reduced zone starting from $\sim 15 \mathrm{~m}$ depth that is created by pyrite oxidation consuming the influx of $\mathrm{O}_{2}$ and $\mathrm{NO}_{3}^{-}$from the water recharge (both in 2006 and 2014). Biotic reductive dechlorination of PCE and TCE takes place as conditions here become manganese/iron reducing, which explains the disappearance of these compounds between $\sim 700$ and $\sim 900 \mathrm{~m}$ downgradient from the source, where the plume crosses the pyrite oxidation zone. Reductive dechlorination of $c D C E$ does not appear to have occurred to a significant extent in this part of the plume in 2006 nor in 2014 , as supported by $\delta^{13} C_{C D E}<\delta^{13-}$ $13 C_{\text {source }}$ and the presence of insufficiently reduced conditions.

\subsection{From $1000 \mathrm{~m}$ to $1500 \mathrm{~m}$}

The fate of $c$ DCE in 2006 after $1000 \mathrm{~m}$ was better evaluated based on studies performed since 2011 that allow a better dual $\mathrm{C}-\mathrm{Cl}$ isotope slope interpretation. It could be concluded that CDCE was likely predominantly abiotically reduced by pyrite in 2006 between $1000 \mathrm{~m}$ and the plume front although biotic degradation may have occurred as well (presence of VC and detection of Dhc). In 2014, the DOC release that led to more reduced conditions seems to have impacted the subsurface to $\sim 1500 \mathrm{~m}$ downgradient of the source area. Indeed, no Fe(II) and lower $\mathrm{SO}_{4}^{2-}$ concentrations are abruptly observed between $\sim 1000$ and $\sim 1500 \mathrm{~m}$ in 2014, indicating that $\mathrm{SO}_{4}^{2-}$ reduction followed by iron sulphide precipitation such as mackinawite and/or Fe(II) sorption on minerals (and potential formation of green rust and other reduced iron species) likely occurred. Such a drop in $\mathrm{Fe}$ (II) and $\mathrm{SO}_{4}^{2-}$ concentrations could also be partially attributed to the absence of pyrite oxidation that resulted from $\mathrm{O}_{2}$ and $\mathrm{NO}_{3}^{-}$consumption in the upper part of the aquifer close to the source after the DOC release, and therefore limited Fe(II) and $\mathrm{SO}_{4}^{2-}$ influx. $c$ DCE degradation is probably occurring in this part of the plume, as indicated by $\delta^{13} \mathrm{C}_{\mathrm{CDE}}>\delta^{13} \mathrm{C}_{\text {source }} 1050 \mathrm{~m}$ downgradient from the source. Based on $\mathrm{C}-\mathrm{Cl}$ isotope data and on the assumption that currently available dual isotope slopes represent the range of slopes associated with the corresponding degradation process, it was also suggested that $c D C E$ is predominantly abiotically reduced in 2014. This is also supported by the VC C isotopic composition which is generally almost depleted compared to that of $\mathrm{CDCE}$. The low VC concentrations could additionally document the occurrence of abiotic degradation to which the possible presence of nonmeasurable surface-bound Fe(II) which is known to catalyze abiotic degradation of some compounds (Elsner et al., 2004; Han et al., 2012), could contribute. On the other hand, the 

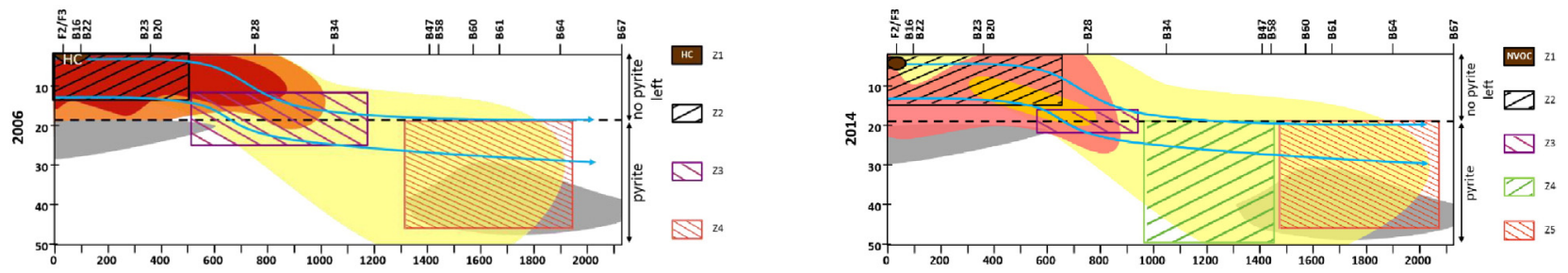

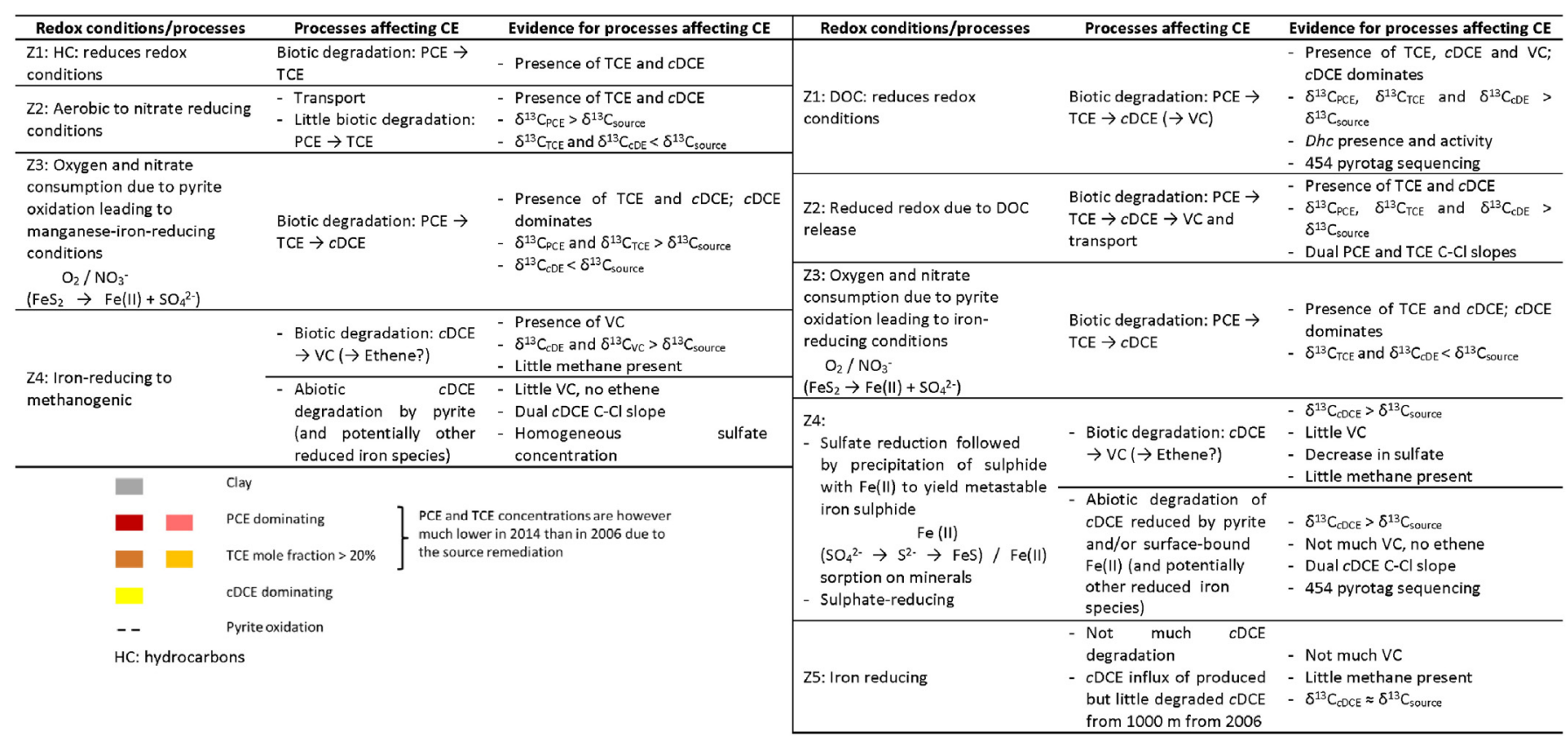

Fig. 11. Overview summarising redox conditions and processes as well as processes affecting chlorinated ethenes (CE) in the subsurface in 2006 and in 2014. 
observed redox conditions are more favorable for biotic reductive $c \mathrm{DCE}$ and $\mathrm{VC}$ dechlorination than before remediation, explaining the occurrence of Dhc and Dhc activity around $1050 \mathrm{~m}$ downgradient in 2014.

\subsection{From $1500 m$ to the plume front}

Further downgradient where the source remediation did not impact the plume ( $>1500 \mathrm{~m}$ ), cDCE does not seem to be degraded, as indicated by the presence of little VC as well as $\delta^{13} \mathrm{C}_{\mathrm{CDE}} \approx \delta^{13} \mathrm{C}_{\text {source. }}$. Moreover, that the plume front extended $\sim 200 \mathrm{~m}$ further in 2014 compared to 2006 (concentration contours, Fig. 5) together with the presence of $c$ DCE in slightly higher concentrations in 2014 in the downgradient part of the plume compared to 2006 suggests that $c D C E$ is still expanding, though slowly (almost steady state). This coincides with the observation of the small extent of $c D C E$ degradation based on isotope data ranging from 7 to $19 \%$. Such an observed difference in the $c$ DCE concentration at the plume front between 2006 and 2014 might also be attributed to a slight lateral change in flow direction. An explanation to the lack of further degradation could be the absence of active degraders in 2014 as depicted in Fig. 7. Finally, it was concluded based on isotope and molecular biology data that the small amounts of VC produced in the downgradient part of the plume is scarcely degraded further.

\section{Assessment of source thermal remediation effect on redox conditions and the fate of chlorinated ethenes}

Due to the contaminant source removal, the overall chlorinated ethene concentrations in and downgradient of the source area dramatically decreased between 2006 and 2014. Although no plume detachment was observed, the source thermal remediation seems to have triggered a change in redox species concentrations, more particularly of iron. Indeed, an increase in DOC in the source zone, likely due to the release of organic matter during the treatment, could support microbial growth triggering in turn changes in redox conditions as a result of electron acceptors consumption such as $\mathrm{O}_{2}$ and $\mathrm{NO}_{3}^{-}$. A chain of redox reactions influenced by the additional presence of pyrite in the aquifer eventually affected the degradation of chlorinated ethenes, which led primarily to an increase of biotic PCE and TCE degradation to $C D C E$ immediately downgradient of the source area and predominantly to an abiotic reduction of $c D C E$ in the plume centre. Intricate situations similar to that of the current study, where iron plays a role in redox reactions and both bacterial and abiotic degradation of chlorinated contaminants occur, have been previously reported (Elsner et al., 2004; Shani et al., 2013; Broholm et al., 2014). This underlines the need for studies that explore the dynamics of geochemical systems where iron is present.

This study thus demonstrates the strength of complementary application of analytical and molecular biology tools to gain insight to processes occurring in the subsurface where a plume of chlorinated ethenes flows in a complex geochemical system.

\section{Acknowledgements}

The authors would like to acknowledge Niels Just and the Region of Southern Denmark for providing a sampling opportunity in the study site and additional funding as well as sharing information relative to the site, and Jesper Gregersen for his precious help in organising and performing field sampling. Orfan Shouakar-Stash and Mirna Stas are acknowledged for measuring $\mathrm{Cl}$ isotopic ratios of $c D C E$. Julien Maillard is acknowledged for critical reading of the manuscript. Torben Dolin (DTU) is thanked for the plume illustrations (Figs. 3, 4, 5 and 7). Alexandra Murray (DTU) is acknowledged for reviewing the English. Three anonymous reviewers are acknowledged for their very helpful comments. This research was completed within the framework of the Marie Curie Initial Training Network ADVOCATE - Advancing sustainable in situ remediation for contaminated land and groundwater, funded by the European Commission, Marie Curie Actions Project No. 265063.

\section{Appendix A. Supplementary data}

Supplementary data to this article can be found online at http://dx.doi.org/10.1016/j.jconhyd.2016.05.003.

\section{References}

Abe, Y., Aravena, R., Zopfi, J., Shouakar-Stash, O., Cox, E., Roberts, J.D., Hunkeler D., 2009. Carbon and chlorine isotope fractionation during aerobic oxidation and reductive dechlorination of vinyl chloride and cis-1,2dichloroethene. Environ. Sci. Technol. 43 (1), 101-107.

Aeppli, C., Holmstrand, H., Andersson, P., Gustafsson, O., 2010. Direct compound-specific stable chlorine isotope analysis of organic compounds with quadrupole GC/MS using standard isotope bracketing. Anal. Chem. 82 (1), 420-426.

Audí-Miró, C., Cretnik, S., Otero, N., Palau, J., Shouakar-Stash, O., Soler, A., Elsner, M., 2013. $\mathrm{Cl}$ and $\mathrm{C}$ isotope analysis to assess the effectiveness of chlorinated ethene degradation by zero-valent iron: evidence fro dual element and product isotope values. Appl. Geochem. 32, 175-183.

Audí-Miró, C., Cretnik, S., Torrentó, C., Rosell, M., Shouakar-Stash, O., Otero, N., Palau, J., Elsner, M., Soler, A., 2015. C, Cl and H compound-specific isotope analysis to assess natural versus $\mathrm{Fe}(0)$ barrier-induced degradation of chlorinated ethenes at a contaminated site. J. Hazard. Mater. 299, 747-754.

Aulenta, F., Majone, M., Verbo, P., Tandoi, V., 2002. Complete dechlorination of tetrachloroethene to ethene in presence of methanogenesis and acetogenesis by an anaerobic sediment microcosm. Biodegradation 13 (6), 411-424

Badin, A., Buttet, G., Maillard, J., Holliger, C., Hunkeler, D., 2014. Multiple dual $\mathrm{C}-\mathrm{Cl}$ isotope patterns associated with reductive dechlorination of tetrachloroethene. Environ. Sci. Technol. 48 (16), 9179-9186.

Bælum, J., Chambon, J.C., Scheutz, C., Binning, P.J., Laier, T., Bjerg, P.L., Jacobsen, C.S., 2013. A conceptual model linking functional gene expression and reductive dechlorination rates of chlorinated ethenes in clay rich groundwater sediment. Water Res. 47 (7), 2467-2478.

Ballapragada, B.S., Stensel, H.D., Puhakka, J.A., Ferguson, J.F., 1997. Effect of hydrogen on reductive dechlorination of chlorinated ethenes. Environ. Sci. Technol. 31 (6), 1728-1734.

BIPM, IEC, IFCC, ISO, IUPAC, IUPAP, OIML, 1993. Guide to the Expression of Uncertainty in Measurement. International Organization for Standardization, Geneva, Switzerland.

Bloom, Y., Aravena, R., Hunkeler, D., Edwards, E., Frape, S.K., 2000. Carbon isotope fractionation during microbial dechlorination of trichloroethene, cis-1,2-dichloroethene, and vinyl chloride: implications for assessment of natural attenuation. Environ. Sci. Technol. 34 (13), 2768-2772.

Bradley, P.M., 2000. Microbial degradation of chloroethenes in groundwater systems. Hydrogeol. J. 8 (1), 104-111.

Bradley, P.M., Chapelle, F.H., 1998. Microbial mineralization of VC and DCE under different terminal electron accepting conditions. Anaerobe 4 (2), 81-87.

Bradley, P.M., Chapelle, F.H., 2000. Aerobic microbial mineralization of dichloroethene as sole carbon substrate. Environ. Sci. Technol. 34 (1), 221-223.

Broholm, M.M., Hunkeler, D., Tuxen, N., Jeannottat, S., Scheutz, C., 2014. Stable carbon isotope analysis to distinguish biotic and abiotic degradation of 1,1,1-trichloroethane in groundwater sediments. Chemosphere $108(0)$, 265-273. 
Butler, E.C., Hayes, K.F., 1999. Kinetics of the transformation of trichloroethylene and tetrachloroethylene by iron sulfide. Environ. Sci. Technol. 33 (12), 2021-2027.

Caporaso, J.G., Kuczynski, J., Stombaugh, J., Bittinger, K., Bushman, F.D., Costello, E.K., et al., 2010. QIIME allows analysis of high-throughput community sequencing data. Nat. Methods 7 (5), 335-336.

Chapelle, F.H., 1996. Identifying redox conditions that favor the natural attenuation of chlorinated ethenes in contaminated ground-water systems. Symposium on Natural Attenuation of Chlorinated Organics in Groundwater.US EPA, Washington, DC, pp. 17-20

Cretnik, S., Thoreson, K.A., Bernstein, A., Ebert, K., Buchner, D., Laskov, C. Haderlein, S., Shouakar-Stash, O., Kliegman, S., McNeill, K., Elsner, M., 2013. Reductive dechlorination of TCE by chemical model Systems in Comparison to Dehalogenating bacteria: insights from dual element isotope analysis (13C/12C, 37Cl/35Cl). Environ. Sci. Technol. 47 (13), 6855-6863.

Cretnik, S., Bernstein, A., Shouakar-Stash, O., Löffler, F., Elsner, M., 2014 Chlorine isotope effects from isotope ratio mass spectrometry suggest intramolecular $\mathrm{C}-\mathrm{Cl}$ bond competition in trichloroethene (TCE) reductive dehalogenation. Molecules 19 (5), 6450-6473.

Damgaard, I., Bjerg, P.L., Bælum, J., Scheutz, C., Hunkeler, D., Jacobsen, C.S. Tuxen, N., Broholm, M.M., 2013a. Identification of chlorinated solvents degradation zones in clay till by high resolution chemical, microbial and compound specific isotope analysis. J. Contam. Hydrol. 146 (0), 37-50.

Damgaard, I., Bjerg, P.L., Jacobsen, C.S., Tsitonaki, A., Kerrn-Jespersen, H., Broholm, M.M., 2013b. Performance of full-scale enhanced reductive dechlorination in clay till. Ground Water Monit. Rem. 33 (1), 48-61.

Duhamel, M., Wehr, S.D., Yu, L., Rizvi, H., Seepersad, D., Dworatzek, S., Cox, E.E., Edwards, E.A., 2002. Comparison of anaerobic dechlorinating enrichment cultures maintained on tetrachloroethene, trichloroethene, cisdichloroethene and vinyl chloride. Water Res. 36 (17), 4193-4202.

Edgar, R.C., Haas, B.J., Clemente, J.C., Quince, C., Knight, R., 2011. UCHIME improves sensitivity and speed of chimera detection. Bioinformatics 27 (16), 2194-2200.

Elsner, M., 2010. Stable isotope fractionation to investigate natural transformation mechanisms of organic contaminants: principles, prospects and limitations. J. Environ. Monit. 12 (11), 2005-2031.

Elsner, M., Schwarzenbach, R.P., Haderlein, S.B., 2004. Reactivity of Fe(II)bearing minerals toward reductive transformation of organic contaminants. Environ. Sci. Technol. 38 (3), 799-807.

Elsner, M., Zwank, L., Hunkeler, D., Schwarzenbach, R.P., 2005. A new concept linking observable stable isotope fractionation to transformation pathways of organic pollutants. Environ. Sci. Technol. 39 (18), 6896-6916.

Elsner, M., Chartrand, M., Vanstone, N., Couloume, G.L., Lollar, B.S., 2008. Identifying abiotic chlorinated ethene degradation: characteristic isotope patterns in reaction products with nanoscale zero-valent iron. Environ. Sci. Technol. 42 (16), 5963-5970.

Fletcher, K.E., Nijenhuis, I., Richnow, H.H., Loffler, F.E., 2011. Stable carbon isotope enrichment factors for cis-1,2-dichloroethene and vinyl chloride reductive dechlorination by dehalococcoides. Environ. Sci. Technol. 45 (7) 2951-2957.

Flynn, S.J., Löffler, F.E., Tiedje, J.M., 2000. Microbial community changes associated with a shift from reductive dechlorination of PCE to reductive dechlorination of cis-DCE and VC. Environ. Sci. Technol. 34 (6), 1056-1061.

Friis, A.K., Albrechtsen, H.J., Heron, G., Bjerg, P.L., 2005. Redox processes and release of organic matter after thermal treatment of a TCE-contaminated aquifer. Environ. Sci. Technol. 39 (15), 5787-5795.

Gossett, J.M., 2010. Sustained aerobic oxidation of vinyl chloride at low oxygen concentrations. Environ. Sci. Technol. 44 (4), 1405-1411.

Haas, B.J., Gevers, D., Earl, A.M., Feldgarden, M., Ward, D.V., Giannoukos, G., Ciulla, D., Tabbaa, D., Highlander, S.K., Sodergren, E., Methé, B., DeSantis, T.Z., Consortium, T.H.M., Petrosino, J.F., Knight, R., Birren, B.W., 2011 Chimeric 16S rRNA sequence formation and detection in Sanger and 454pyrosequenced PCR amplicons. Genome Res. 21 (3), 494-504.

Han, Y.-S., Hyun, S.P., Jeong, H.Y., Hayes, K.F., 2012. Kinetic study of cisdichloroethylene (cis-DCE) and vinyl chloride (VC) dechlorination using green rusts formed under varying conditions. Water Res. 46 (19), 6339-6350.

Hartmans, S., de Bont, J.A.M., Tramper, J., Luyben, K.C.A.M., 1985. Bacterial degradation of vinyl chloride. Biotechnol. Lett. 7 (6), 383-388.

Hoelen, T.P., Reinhard, M., 2004. Complete biological dehalogenation of chlorinated ethylenes in sulfate containing groundwater. Biodegradation 15 (6), 395-403.

Holt, B.D., Sturchio, N.C., Abrajano, T.A., Heraty, L.J., 1997. Conversion of chlorinated volatile organic compounds to carbon dioxide and methyl chloride for isotopic analysis of carbon and chlorine. Anal. Chem. 69 (14), 2727-2733.

Hunkeler, D., Van Breukelen, B.M., Elsner, M., 2009. Modeling chlorine isotope trends during sequential transformation of chlorinated ethenes. Environ. Sci. Technol. 43 (17), 6750-6756.
Hunkeler, D., Elsner, M., Aelion, C.M., Hohener, P., Hunkeler, D., Aravena, R., 2010. Environmental Isotopes in Biodegradation and Bioremediation.

Hunkeler, D., Abe, Y., Broholm, M.M., Jeannottat, S., Westergaard, C., Jacobsen, C.S., Aravena, R., Bjerg, P.L., 2011. Assessing chlorinated ethene degradation in a large scale contaminant plume by dual carbon-chlorine isotope analysis and quantitative PCR. J. Contam. Hydrol. 119 (1-4), 69-79.

Hunkeler, D., Laier, T., Breider, F., Jacobsen, O.S., 2012. Demonstrating a natural origin of chloroform in groundwater using stable carbon isotopes. Environ. Sci. Technol. 46 (11), 6096-6101.

Jeong, H.Y., Anantharaman, K., Han, Y.-S., Hayes, K.F., 2011. Abiotic reductive dechlorination of cis-dichloroethylene by Fe species formed during iron- or sulfate-reduction. Environ. Sci. Technol. 45 (12), 5186-5194.

Krajmalnik-Brown, R., Hölscher, T., Thomson, I.N., Saunders, F.M., Ritalahti, K.M., Löffler, F.E., 2004. Genetic identification of a putative vinyl chloride reductase in dehalococcoides sp. strain BAV1. Appl. Environ. Microbiol. 70 (10), 6347-6351.

Kuder, T., van Breukelen, B.M., Vanderford, M., Philp, P., 2013. 3D-CSIA: carbon, chlorine, and hydrogen isotope fractionation in transformation of TCE to ethene by a dehalococcoides culture. Environ. Sci. Technol. 47 (17), 9668-9677.

Lee, W., Batchelor, B., 2002a. Abiotic reductive dechlorination of chlorinated ethylenes by iron-bearing soil minerals. 1. Pyrite and magnetite. Environ. Sci. Technol. 36 (23), 5147-5154.

Lee, W., Batchelor, B., 2002b. Abiotic reductive dechlorination of chlorinated ethylenes by iron-bearing soil minerals. 2. Green rust. Environ. Sci. Technol. 36 (24), 5348-5354.

Liang, X., Paul Philp, R., Butler, E.C., 2009. Kinetic and isotope analyses of tetrachloroethylene and trichloroethylene degradation by model Fe(II)bearing minerals. Chemosphere 75 (1), 63-69.

Löffler, F.E., Ritalahti, K.M., Zinder, S.H., 2013. Dehalococcoides and reductive dechlorination of chlorinated solvents. In: Stroo, H.F., Leeson, A., Ward, C.H. (Eds.), SERDP ESTCP Environmental Remediation Technology Bioaugmentation for Groundwater Remediation. Springer, New York, NY, pp. 39-88.

Martins, P., Cleary, D.F.R., Pires, A.C.C., Rodrigues, A.M., Quintino, V., Calado, R., Gomes, N.C.M., 2013. Molecular analysis of bacterial communities and detection of potential pathogens in a recirculating aquaculture system for Scophthalmus maximus and Solea senegalensis. PLoS ONE 8 (11), e80847.

McCormick, M.L., Adriaens, P., 2004. Carbon tetrachloride transformation on the surface of nanoscale biogenic magnetite particles. Environ. Sci. Technol. 38 (4), 1045-1053.

Meckenstock, R.U., Elsner, M., Griebler, C., Lueders, T., Stumpp, C., Dejonghe, W., Bastiaens, L.L., Springael, D., Smolders, E., Boon, N., Agathos, S.N., Sorensen, S.R., Aamand, J., Albrechtsen, H.J., Bjerg, P.L., Schmidt, S., Huang, W.E., Van Breukelen, B.M., 2015. Biodegradation: updating the concepts of control for microbial clean-up in contaminated aquifers. Environ. Sci. Technol.

Müller, J.A. Rosner, B.M., von Abendroth, G., Meshulam-Simon, G., McCarty, P.L, Spormann, A.M., 2004. Molecular identification of the catabolic vinyl chloride reductase from dehalococcoides sp. strain VS and its environmental distribution. Appl. Environ. Microbiol. 70 (8), 4880-4888.

Newmark, R.L., Aines, R.D., 1995. Summary of the LLNL Gasoline Spill Demonstration - Dynamic Underground Stripping Project. U. S. D. o. Energy, Lawrence Livermore National Laboratory.

Novais, R.C., Thorstenson, Y.R., 2011. The evolution of Pyrosequencing® for microbiology: from genes to genomes. J. Microbiol. Methods 86 (1), 1-7.

Paul, E.A.a.,C.,.F.E., 1996. Soil Microbiology and Biochemistry. San Diego, CA, USA.

Paul, L., Herrmann, S., Bender Koch, C., Philips, J., Smolders, E., 2013. Inhibition of microbial trichloroethylene dechorination by Fe (III) reduction depends on Fe mineralogy: a batch study using the bioaugmentation culture KB-1. Water Res. 47 (7), 2543-2554.

Pilloni, G., Granitsiotis, M.S., Engel, M., Lueders, T., 2012. Testing the limits of 454 pyrotag sequencing: Reproducibility, quantitative assessment and comparison to T-RFLP fingerprinting of aquifer microbes. PLoS ONE 7 (7), e40467.

Postma, D., Boesen, C., Kristiansen, H., Larsen, F., 1991. Nitrate reduction in an unconfined Sandy aquifer: water chemistry, reduction processes, and geochemical modeling. Water Resour. Res. 27 (8), 1944-7973.

Reddy, C., Drenzek, N., Eglinton, T., Heraty, L., Sturchio, N., Shiner, V., 2002. Stable chlorine intramolecular kinetic isotope effects from the abiotic dehydrochlorination of DDT. Environ. Sci. Pollut. Res. 9 (3), 183-186.

Renpenning, J., Keller, S., Cretnik, S., Shouakar-Stash, O., Elsner, M., Schubert, T., Nijenhuis, I., 2014. Combined $\mathrm{C}$ and $\mathrm{Cl}$ isotope effects indicate differences between corrinoids and enzyme (Sulfurospirillum multivorans PceA) in reductive dehalogenation of tetrachloroethene, but not trichloroethene. Environ. Sci. Technol. 48 (20), 11837-11845.

Scheutz, C., Durant, N.D., Dennis, P., Hansen, M.H., Jørgensen, T., Jakobsen, R., Cox, E.E., Bjerg, P.L., 2008. Concurrent ethene generation and growth of dehalococcoides containing vinyl chloride reductive dehalogenase genes during an enhanced reductive dechlorination field demonstration. Environ. Sci. Technol. 42 (24), 9302-9309. 
Shani, N., Rossi, P., Holliger, C., 2013. Correlations between environmental variables and bacterial community structures suggest $\mathrm{Fe}(\mathrm{III})$ and vinyl chloride reduction as antagonistic terminal electron-accepting processes. Environ. Sci. Technol. 47 (13), 6836-6845.

Shouakar-Stash, O., Drimmie, R.J., Zhang, M., Frape, S.K., 2006. Compoundspecific chlorine isotope ratios of TCE, PCE and DCE isomers by direct injection using CF-IRMS. Appl. Geochem. 21 (5), 766-781.

Slater, G.F., Lollar, B.S., Sleep, B.E., Edwards, E.A., 2001. Variability in carbon isotopic fractionation during biodegradation of chlorinated ethenes: implications for field applications. Environ. Sci. Technol. 35 (5), 901-907.

Sleep, B.E., Ma, Y., 1997. Thermal variation of organic fluid properties and impact on thermal remediation feasibility. J. Soil Contam. 6 (3), 281-306.

Smits, T.H.M., Assal, A., Hunkeler, D., Holliger, C., 2011. Anaerobic degradation of vinyl chloride in aquifer microcosms. J. Environ. Qual. 40, 915-922.

Tiehm, A., Schmidt, K.R., 2011. Sequential anaerobic/aerobic biodegradation of chloroethenes-aspects of field application. Curr. Opin. Biotechnol. 22 (3), 415-421.

Tobiszewski, M., Namieśnik, J., 2012. Abiotic degradation of chlorinated ethanes and ethenes in water. Environ. Sci. Pollut. Res. Int. 19 (6), 1994-2006.

van der Zaan, B., Hannes, F., Hoekstra, N., Rijnaarts, H., de Vos, W.M., Smidt, H. Gerritse, J., 2010. Correlation of dehalococcoides 16S rRNA and chloroethene-reductive dehalogenase genes with geochemical conditions in chloroethene-contaminated groundwater. Appl. Environ. Microbiol. 76 (3), 843-850
Vogel, T.M., Criddle, C.S., McCarty, P.L., 1987. ES critical reviews: transformations of halogenated aliphatic compounds. Environ. Sci. Technol. 21 (8), 722-736.

von Schnakenburg, P., 2013. In situ thermal remediation of contaminated sites a technique for the remediation of source zones. CityChlor.

Wagner, A., Segler, L., Kleinsteuber, S., Sawers, G., Smidt, H., Lechner, U., 2013. Regulation of reductive dehalogenase gene transcription in Dehalococcoides mccartyi. Philos. Trans. R. Soc. Lond. B 368 (1616).

Wang, Q., Garrity, G.M., Tiedje, J.M., Cole, J.R., 2007. Naïve Bayesian classifier for rapid assignment of rRNA sequences into the new bacterial taxonomy. Appl. Environ. Microbiol. 73 (16), 5261-5267.

Westergaard, C., Broholm, M.M., Nyegaard, T., 2011. Tidligere Renseri, Clip Rens Fladhojvej 1, Rodekro Monitering. Orbicon, Orbicon.

Wiedemeier, T.H., Newell, C.J., Rifai, H.S., Wilson, J.T., 1999. Natural Attenuation of Fuels and Chlorinated Solvents.

Wiegert, C., Mandalakis, M., Knowles, T., Polymenakou, P., Aeppli, C., Machackova, J., Holmstrand, H., Evershed, R.P., Pancost, R., Gustafsson, O., 2013. Carbon and chlorine isotope fractionation during microbial degradation of tetra- and trichloroethene. Environ. Sci. Technol. 47 (12), 6449-6456.

Yang, Y., Löffler, F.E., 2015. Reductive dechlorination of vinyl chloride in the absence of dehalococcoides mccartyi. Third International Symposium on Bioremediation and Sustainable Remediation Technologies. Battelle, Miami, Florida. 